\title{
Use of immunoglobulin-binding bacterial proteins in immunodetection.
}

\section{Angel Justiz-Vaillant ${ }^{1} *$ MD/PhD, Belkis Ferrer-Cosme ${ }^{2,3}$ MD, Albert Vera ${ }^{4}$ MD.}

${ }^{1}$ Department of Para-clinical Sciences. Faculty of medical Sciences. University of the West Indies. St. Augustine. Trinidad and Tobago. West Indies. angel.vaillant@sta.uwi.edu

${ }^{2}$ Immunology Laboratory. Clinical Laboratory. "Saturnino Lora Torres” Provincial Teaching Clinical Surgical Hospital. Province of Santiago de Cuba. Cuba. bfcosme9@gmail.com

${ }^{3}$ Higher Institute of Medical Sciences of Santiago de Cuba. Province of Santiago. Cuba.

${ }^{4}$ Immunology Section. Department of Pre-Clinical Sciences. University of Medical Sciences of Cienfuegos. Province of Cienfuegos. Cuba. veraa34@aol.com

*Corresponding author's mailing address: Angel Justiz-Vaillant. Pathology and Microbiology Unit. Eric Williams Medical Science Complex. Building 5, room 30, San Juan. Trinidad and Tobago. West Indies. Telephone:1(868) 645-4673, ext 2330.

\begin{abstract}
One of the aim of this study was to make universal chimeric conjugates to react with both avian and mammalian immunoglobulins in enzyme-linked immunosorbent assays (ELISAs). The periodate method was used in the conjugation process of cross-linking horseradish peroxidase to immunoglobulin-binding proteins (IBP) including staphylococcal protein $\mathrm{A}(\mathrm{SpA})$, streptococcal protein $\mathrm{G}(\mathrm{SpG})$ and peptostreptococcal protein $\mathrm{L}(\mathrm{SpL})$. By mixing up these three conjugates another four hybrid protein conjugates were created including protein LA (SpLA), protein LG (SpLG), protein AG (SpAG) and protein LAG (PLAG). Thirtyfive ELISAs were standardized by a probabilistic combination of these immunoreagents. By using a panel of mainly mammalian immunoglobulins their reproducibility was checked by the determination of coefficient of variations (CV) for each one of the IgG-IBP binding. The source of immunoglobulins was their purification by affinity chromatography using a commercially available kit (PURE-1A). The other aim was to immunize chicken with the peptide fragment 254-274 of gp120 to produce anti-HIV peptide hyper-immune egg. Cats and rats were fed these eggs for a determined period until they produced the anti-HIV peptide antibody, which was tested by an indirect SpLA-ELISA and dot blot analysis that corroborated the production of antiHIV antibodies by the mammalian species including positive humans samples for HIV. We conclude that the single and hybrid immunoglobulin-binding protein were effective in their binding capacity to immunoglobulins from a variety of mammalian species. The potential use of this proteins is in the arena of immunodiagnosis and immunoglobulin detection. Dot blot analysis proves effective in the detection of HIV anti-gp120 antibodies in several animal species. These antibodies can be used as reagents in the development of immunodiagnostic tests or experimental vaccines.
\end{abstract}

Keywords: Zoology, bacterial proteins, enzyme-linked immunosorbent assay (ELISA) 


\section{Introduction}

Several bacterial immunoglobulin (Ig)-receptors have been identified. They have proved to be powerful tools for binding, detection, and purification of immunoglobulins [1]. The better studied bacterial Ig receptors include the protein A (SpA) of Staphylococcus aureus [2]; protein $\mathrm{G}(\mathrm{SpG})$ of Streptococci $[3,4]$; and protein L (SpL) originally isolated from the cell wall of the anaerobic bacterium Peptostreptococcus magnus [5].

These bacterial proteins displayed on the cell wall of microorganisms play an important role in bacterial escape mechanisms from the immune system. They cause activation of the complement system by the classical pathway, polyclonal activation of B-lymphocytes, inhibition of phagocytosis and other effects [6-8]. In addition, they have the biological property of binding to a wide range of mammalian and non-mammalian immunoglobulins.

This binding does not interfere with the antigen binding sites on the immunoglobulin receptors. These receptors have been called immunoglobulin-binding protein, IBP [9-14]. Protein A and G have been used as immunological tools in serological tests used in the immunodiagnosis of infectious diseases, such as Borrelia burgdorferi in zoo animals [14]. Ongoing studies suggest that the bacterial Ig receptors are also potential tools in biomedical research, therapy of human diseases, biotechnology, and industry.

Several bacterial immunoglobulins (Ig)-receptors have been identified in recent years. Indeed, they have proved to be robust tools for binding, detection, and purification of immunoglobulins. Among the better-studied bacterial Ig-receptors include the protein A (SpA) of Staphylococcus aureus, protein $\mathrm{G}(\mathrm{SpG})$ of Streptococci, and protein $\mathrm{L}(\mathrm{SpL})$ originally isolated from the cell wall of the anaerobic bacterium Peptostreptococcus magnus. These bacterial antigens displayed on the cell wall of microorganisms play an essential role in bacterial escape mechanisms from the immune system. They cause the complement system's activation by the classical pathway, polyclonal activation of B-lymphocytes, phagocytosis inhibition, and other effects [1-5].

Besides, they have the biological property of binding to a wide range of mammalian and nonmammalian immunoglobulins. This binding does not interfere with the antigen-binding sites on the immunoglobulin receptors. They have been called immunoglobulin-binding protein, IBP. $\mathrm{SpA}$ and $\mathrm{SpG}$ have been used as immunological reagents in serological tests used in the immunodiagnosis of infectious microorganisms, such as Borrelia burgdorferi, in zoo animals. Ongoing studies suggest that the immunoglobulin-binding proteins (IBP) are also practical tools in biomedical research and biotechnology [6-12].

SpA has molecular weight (MW) approximately $42 \mathrm{kDa}$ [1]. It has the capacity to bind to the Fc fragment of IgG produced by many animal species, including humans, dogs, rabbits, hamsters, monkeys, and others $[6,13,14]$. The native SpA consists of five domains. Of these, four-show high structural homology, containing approximately 58 amino acids and have the capacity of binding to Fc regions of IgG [1]. 
SpG is a type III bacterial Fc receptor. It is a small globular protein produced by several Streptococcal species and comprises 2 or 3 nearly identical domains, each containing 55 amino acids (aa). SpG binds to the Fc regions of IgG from many mammalian species [15-17].

The molecule contains five homologous " $\mathrm{B}$ " repeats of 72-76 aa, and responsible for the interaction with Ig-L chains [18]. SpL is composed of an alpha-helix packed against a 4-stranded beta-sheet [19]. The SpL binds firmly to human kappa light chain subclasses I, III, and IV from the five human Ig classes. Also, SpL binds to other mammalian Ig molecules [5].

In this paper several Immunoglobulins from diverse animal species were purified and used for the standardization of 35 enzyme-linked immunosorbent assays based on immunoglobulinbinding proteins. Their affinity, intra- and inter-assay coefficient of variation were assessed as a measure of the reproducibility of assays, and surprisingly they were all reproducible and sensitive enough for the evaluation of the different affinity of IBP to these antibodies.

\section{Materials and Methods}

A commercial protein-A affinity chromatography called PURE-1A (Sigma-Aldrich.) was used to purify mammalian immunoglobulins from the serum of different mammalian species including horse, mule, dog, coyote, and others. [20]. The instructions of the manufacturer were followed in performing this procedure. Briefly Anti-SpA containing serum is first loaded onto the Protein A Cartridge where the IgG is immobilized. The Protein A Cartridge is then washed to remove excess unbound proteins. The Desalting Cartridge is readied for use by reactivating with HEPES buffer. The Protein A Cartridge and Desalting Cartridge are then connected via the Luer lock fittings and the Elution Buffer is introduced. The eluate contains the purified $\operatorname{IgG}$ at a physiological $\mathrm{pH}$. Both cartridges may be regenerated and stored for future use. The 10\% nondenaturing sodium dodecyl sulphate polyacrylamide gel electrophoresis (SDS-PAGE) of sera and purified immunoglobulins was carried out [21].

Other immunoglobulins used in these experiments are the ostrich IgY purified by affinity chromatography [22] and commercially available IgGs from the pigs, mice, cats, rats, rabbits, and bovine IgG (Sigma-Aldrich).

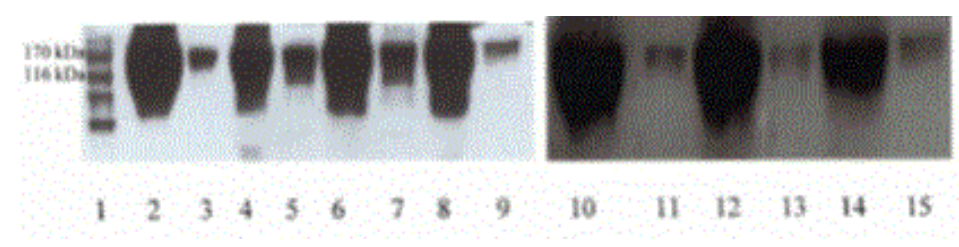

Figure 1: The $10 \%$ non-denaturing SDS-PAGE of sera and purified immunoglobulins (IgGs). Lane 1 molecular weight (MW) marker, lane 2 mule serum, lane 3 mule $\mathrm{IgG}$, lane 4 donkey serum, lane 5 donkey $\mathrm{IgG}$, lane 6 horse serum, lane 7 horse $\mathrm{IgG}$, lane 8 dog serum, lane 9 dog IgG, lane 10 skunk serum, lane 11 skunk IgG, lane 12 coyote serum, lane 13 coyote IgG, lane 14 raccoon serum and lane 15 raccoon IgG. Purified IgGs have a molecular weight of approximately $150 \mathrm{Kda}$. 
The chicken IgY fraction was isolated by the chloroform-polyethylene glycol (PEG) method [23]. The chicken egg was washed with warm water and the egg yolk was separated from the egg white. The membrane was broken, and the egg yolk collected and diluted 1:3 in phosphate buffered saline (PBS), $\mathrm{pH}$ 7.4. To $1 / 3$ of the egg yolk mixture an equal volume of chloroform was added, the mixture was then shaken and centrifuged for $30 \mathrm{~min}(1000 \times \mathrm{g}$, RT). The supernatant was decanted and mixed with PEG 6000 (12\%, w/v), stirred and incubated for $30 \mathrm{~min}$ (RT). The mixture was then centrifuged as previously described. The precipitate containing IgY was dissolved in PBS (pH 7.4) at a volume equivalent to $1 / 6$ of the original volume of the egg yolk and dialyzed against $1 \mathrm{~L}$ of PBS (pH: 7.4 for $24 \mathrm{~h}$ at $4^{\circ} \mathrm{C}$ ). The chicken IgY was removed from the dialysis tubing. IgY concentration was determined by the Bradford method. IgY samples were stored at $-20^{\circ} \mathrm{C}$. Horseradish peroxidase (HRP) labelled SpL, SpA or SpG conjugates were prepared using the periodate method described by Nakane and Kawoi [24,25]. The PLAG-HRP conjugate along with SpLA-HRP, SpLG-HRP and $\mathrm{SpAG-HRP}$ were prepared by mixing at room temperature $50 \mu$ of each SpL-HRP, SpA-HRP and SpG-HRP.

\section{Basic ELISA protocol.}

The 96 well microtitre plate is coated overnight at $4^{\circ} \mathrm{C}$ with $2 \mu \mathrm{g} / \mu 1$ per well of a mixture of $\mathrm{SpA}, \mathrm{SpG}, \mathrm{SpL}$ or their combinations SpAG, SpLG, SpLA or PLAG in carbonate-bicarbonate buffer $\mathrm{pH}$ 9.6. Then plate is treated with bovine serum albumin solution and washed $4 \mathrm{X}$ with PBS-Tween. $50 \mu \mathrm{l}$ of immunoglobulins $(1 \mathrm{mg} / \mathrm{ml})$ is added and incubated for $1.30 \mathrm{~h}$ at room temperature and the microplate is then rewashed $4 \mathrm{X}$ with PBS-Tween. Then $50 \mu 1$ of a peroxidase-labeled-bacterial protein diluted to 1:3000-1:5000 in PBS-non-fat milk is added to each well and incubated for $1.30 \mathrm{~h}$ at RT. After that, the plate is washed $4 \mathrm{X}$ with PBS-Tween. Pipette $50 \mu \mathrm{l}$ of 3,3',5,5' - tetramethylbenzidine (TMB; Sigma-Aldrich) to each well. The reaction is stopped with $50 \mu \mathrm{l}$ of $3 \mathrm{M} \mathrm{H} 2 \mathrm{SO} 4$ solution. The plate is visually assessed for the development of colour and read in a microplate reader at $450 \mathrm{~nm}$. The assay is performed 3 times during the same day for the calculation of the intra-assay coefficient of variation, and once in 3 alternative days. A cut-off point is calculated as the mean of the optical density of negative controls times two [25].

The immunoglobulin-binding protein affinity to immunoglobulins are classified as weekly (+) and goes from the lower limit of the cut-off point to below the cut-off point times two value. Moderate binding affinity (++) goes from the lower limit of cut-off point times two to the below value of the cut-off point times 3 and strong binding affinity (+++) is an equal or higher value of the cut-off point times three. For instance, the mode of cut-off point calculated among the 35 assays was 0.30 . The binding affinity of immunoglobulin binding-protein can be calculated as follows:

- From 0.30-0.59(+)

- From 0.60-0.89 (++)

- From $>0.90(+++)$ 
Preparation of HIV immunogens: It was used a peptide fragment of gp120 from HIV gp120 (254-274): Cys-Thr-His-Gly-lle-Arg-Pro-Val-Val-Ser-Thr-Gln-LeuLeu-Leu-Asn-Gly-Ser-LeuAla-Glu [26]; that was conjugated to keyhole limpet hemocynin (KLH) by the glutaraldehyde method as previously described [27]. Chicken immunization with KLH-gp120 HIV fragment (254- 274). Two healthy layer chickens (brown Leghorn), aged approximately 6 months, were injected intramuscularly at multiple sites on the breast with the peptide-KLH conjugate and they were immunized on day $0,15,60$ as described previously. The eggs were collected postimmunization to test for anti-HIV antibodies [27].

\section{Oral immunization of cats}

Feeding of cats with hyper-immune eggs The anti-gp120 positive eggs were fed to five (5) adult cats, 2-3 years old (1 male and 4 female). Each cat received on average, of 2 eggs diluted in 5 volumes of soya milk weekly for 10 weeks. Of the 5 cats used in the study, 3 were fed hyperimmune eggs (anti-gp120), while the remaining 2 cats were fed eggs from non-immunized chickens. And these two cats that were fed with eggs from non-immunized chickens were used as controls. Blood samples $(2 \mathrm{ml})$ were collected from each cat, after completion of the feeding and were tested for anti-HIV antibodies by an indirect HIV ELISA [27].

Whole egg was fed to 3 rats $(2-3 \mathrm{ml})$ by gastric intubation; weekly for 9 weeks and during the last week, they were fed daily. Two rats where fed HIV non-hyperimmune eggs as a negative control. Blood sample $(0.5 \mathrm{ml})$ were drawn for testing for anti-HIV peptide antibodies by ELISA [27] and confirmative dot blot analyses [28].

\section{ELISA for detection of anti-HIV antibodies in eggs}

The 96 well polystyrene microplates (U-shaped bottom) were coated with $50 \mathrm{ng}$ of the synthetic HIVgp-120 peptide in coating buffer overnight at $4^{\circ} \mathrm{C}$. The microplates were washed 4 times (PBSTween-20) and blocked with 3\% non-fat milk in PBS, $25 \mu \mathrm{l} /$ well, 1h, RT. The microplates were washed 4 times (PBS-Tween-20) and triplicates of $25 \mu 1$ of WSF of the egg yolk in PBS non-fat milk were added. After incubation for $90 \mathrm{~min}$ at RT the microplates were washed 4 times and $25 \mu \mathrm{l}$ of rabbit anti-chicken IgY-HRP diluted 1:30,000 was added and the microplates were then incubated for $1 \mathrm{~h}$ at RT, washed four times. Tetramethylbenzidine (TMB) solution (50 $\mu \mathrm{l})$ was added to each well. After a further incubation of $15 \mathrm{~min}$ in the dark, the reaction was stopped and read in a microplate reader at $450 \mathrm{~nm}$. Geometric mean antibody titer was calculated using Perkins method as previously reported [27].

\section{Indirect ELISA for detection of anti-HIV antibodies in cats or rats}

The ELISA assay described above (with modifications) was used to determine the presence of anti-HIV antibodies in cat or rat sera. The modifications were that triplicates of 1/16 dilutions of cat or rat serum samples in PBS non-fat milk were added. After incubation for $90 \mathrm{~min}$ at RT the microplates were washed $4 \mathrm{X}$ (PBS-Tween 20) and $25 \mu$ l of protein LA-HRP diluted 1:3000 (Sigma) was added and the microplates were then incubated for $1 \mathrm{~h}$ at RT. Then, microplates were washed four times. Tetramethylbenzidine (TMB) solution (50 $\mu \mathrm{l})$ was added to each well. 
After a further incubation of 15 min in the dark, the reaction was stopped and read with stop solution and the microplates were read in a microplate reader at $450 \mathrm{~nm}$ [27].

\section{Dot Blot analyses for the detection of anti-HIV peptide antibodies in cats and rats.}

A dot blot is a technique in molecular biology used to detect biomolecules, and for detecting, analyzing, and identifying proteins. Briefly, $2 \mu 1$ of serum from cats, or rats in addition to human serum (positive control) and chicken IgY (a negative control) were blotted onto nitrocellulose paper placed in a BioDot SF apparatus (Bio-Rad Laboratories, Richmond, CA, USA). The membrane was blocked with $5 \mu \mathrm{L} /$ well of fetal bovine serum with $1 \%$ Tris buffer saline, $\mathrm{pH}: 7.4$. After that, $5 \mu \mathrm{L}$ of a commercial conjugate (peroxidase-labeled HIV proteins; Murex Diagnostics, Norcross, USA) was added to the nitrocellulose membrane for 1 hour at RT, washed and allowed to drain by gravity. Finally, $5 \mu \mathrm{L}$ of the substrate 3,3',5,5'tetramethylbenzidine (Sigma-Aldrich) was added and the mixture was incubated for $20 \mathrm{~min}$ in the dark. The reaction was stopped by washing the wells with distilled water under a vacuum. The nitrocellulose membrane was left to dry, visualized and photographed [28].

\section{Statistical analysis}

Statistical Package for the Social Sciences (SPSS) version 25 was used for the calculation of the coefficients of variation.

Ethical approval: This research was approved by the University of West Indies (UWI) Ethics Committee (Mona Campus) in Jamaica, West Indies.

\section{Results}

SpA-SpA sandwich ELISA: This ELISA is used to study the interaction of Staphylococcal protein-A (SpA) with diverse mammalian and avian immunoglobulins. The 96 well microtitre plate is coated overnight at $4^{\circ} \mathrm{C}$ with $2 \mu \mathrm{g} / \mu \mathrm{l}$ per well of SpA in carbonate-bicarbonate buffer $\mathrm{pH}$ 9.6. Then plate is treated with bovine serum albumin solution and washed $4 \mathrm{X}$ with PBS-Tween. $50 \mu \mathrm{l}$ of immunoglobulins $(1 \mathrm{mg} / \mathrm{ml})$ is added and incubated for $1.30 \mathrm{~h}$ at room temperature and the microplate is then rewashed $4 \mathrm{X}$ with PBS-Tween. Then $50 \mu 1$ of peroxidase-labeled-SpA .2.0conjugate diluted 1:5000 in PBS-non-fat milk is added to each well and incubated for 1.30h at RT. The plate is washed $4 \mathrm{X}$ with PBS-Tween. Pipette $50 \mu \mathrm{l}$ of 3,3',5,5' - tetramethylbenzidine (TMB; Sigma-Aldrich) to each well. The reaction is stopped with $50 \mu 1$ of 3M H2SO4 solution. The plate is visually assessed for the development of colour and read in a microplate reader at $450 \mathrm{~nm}$. A cut-off point is calculated as the mean of the optical density of negative controls times two. The higher the OD value the higher will be the affinity of SpA to avian immunoglobulins. The cut-off point was 0.30 . 
Table 1. SpA-SpA sandwich ELISA

\begin{tabular}{|l|c|c|c|c|}
\hline Immunoglobulins & XOD results & Binding affinity & $\begin{array}{l}\text { Coefficient of } \\
\text { variation }(\mathbf{C V}) \\
\text { intra-assay }(\%)\end{array}$ & $\begin{array}{l}\text { CV inter-assay } \\
(\%)\end{array}$ \\
\hline Mule IgG & 0.40 & + & 2.53 & 4.44 \\
\hline Donkey IgG & 0.35 & + & 4.89 & 6.35 \\
\hline Horse IgG & 0.56 & ++ & 3.67 & 5.38 \\
\hline Dog IgG & 1.44 & +++ & 3.03 & 4.71 \\
\hline Skunk IgG & 1.10 & +++ & 2.28 & 4.11 \\
\hline Coyote IgG & 0.80 & ++ & 4.18 & 7.09 \\
\hline Raccoon IgG & 1.52 & +++ & 4.26 & 4.75 \\
\hline Ostrich IgY & 0.42 & + & 3.30 & 9.68 \\
\hline Pig IgG & 1.56 & +++ & 4.14 & 7.47 \\
\hline Mouse IgG & 1.48 & +++ & 2.27 & 4.03 \\
\hline Bovine IgG & 0.65 & ++ & 3.54 & 4.15 \\
\hline Rabbit IgG & 1.28 & +++ & 2.73 & 4.02 \\
\hline Chicken IgY & 0.15 & - & 2.30 & 3.89 \\
\hline Cat IgG & 1.46 & +++ & 3.36 & 5.70 \\
\hline Rat IgG & 0.39 & + & 4.09 & 6.83 \\
\hline
\end{tabular}

Table 1 shows the SpA-SpA sandwich ELISA. It was very effective. It demonstrated the strong binding affinity of IgG from diverse mammalian species including dog, skunk, raccoon, pig, mouse, rabbit, and cat. The chicken IgY did not bind to SpA. Some of these interactions have been previously cited $[2,9,6,25]$.

SpG-SpG Sandwich ELISA: This ELISA is used to study the interaction of streptococcal protein-G (SpG) with different mammalian and avian immunoglobulins. The 96 well microtitre plate is coated overnight at $4^{\circ} \mathrm{C}$ with $2 \mu \mathrm{g} / \mu \mathrm{l}$ per well of $\mathrm{SpG}$ in carbonate-bicarbonate buffer $\mathrm{pH}$ 9.6. Then plate is treated with bovine serum albumin solution and washed $4 \mathrm{X}$ with PBS-Tween. $50 \mu \mathrm{l}$ of immunoglobulins $(1 \mathrm{mg} / \mathrm{ml})$ is added and incubated for $1.30 \mathrm{~h}$ at room temperature and the microplate is then rewashed $4 \mathrm{X}$ with PBS-Tween. Then $50 \mu 1$ of peroxidase-SpG conjugate diluted 1:5000 in PBS-non-fat milk is added to each well and incubated for 1.30h at RT. The plate is washed $4 \mathrm{X}$ with PBS-Tween. Pipette $50 \mu \mathrm{l}$ of TMB (Sigma-Aldrich) to each well. The reaction is stopped with $50 \mu \mathrm{l}$ of $3 \mathrm{M} \mathrm{H} 2 \mathrm{SO} 4$ solution. The plate is visually assessed for the development of colour and read in a microplate reader at $450 \mathrm{~nm}$. A cut-off point is calculated as the mean of the optical density of negative controls times two. The higher the OD value the higher will be the affinity of SpG to mammalian immunoglobulins. The cut-off point is 0.28 . 
Table 2. SpG-SpG Sandwich ELISA

\begin{tabular}{|c|c|c|c|c|}
\hline Immunoglobulins & XOD results & Binding affinity & $\begin{array}{l}\text { Coefficient of } \\
\text { variation }(\mathrm{CV}) \\
\text { intra-assay }(\%)\end{array}$ & $\begin{array}{l}\text { CV inter-assay } \\
(\%)\end{array}$ \\
\hline Mule IgG & 0.96 & +++ & 3.57 & 5.28 \\
\hline Donkey IgG & 0.80 & +++ & 3.89 & 5.35 \\
\hline Horse IgG & 1.05 & +++ & 4.98 & 7.38 \\
\hline Dog IgG & 1.33 & +++ & 3.03 & 8.70 \\
\hline Skunk IgG & 1.24 & +++ & 5.63 & 9.23 \\
\hline Coyote IgG & 0.47 & + & 2.70 & 6.05 \\
\hline Raccoon IgG & 0.42 & + & 3.28 & 6.60 \\
\hline Ostrich IgY & 0.08 & - & 2.85 & 8.68 \\
\hline Pig IgG & 1.36 & +++ & 5.09 & 10.3 \\
\hline Mouse IgG & 1.55 & +++ & 3.06 & 7.00 \\
\hline Bovine IgG & 1.49 & +++ & 4.96 & 8.63 \\
\hline Rabbit IgG & 1.25 & +++ & 5.83 & 9.28 \\
\hline Chicken IgY & 0.14 & - & 3.50 & 5.06 \\
\hline Cat IgG & 0.18 & - & 3.01 & 4.60 \\
\hline Rat IgG & 0.93 & +++ & 5.83 & 8.74 \\
\hline
\end{tabular}

Table 2 shows the SpG-SpG sandwich ELISA, which depicted the interactions between SpG and IgGs from mules, donkeys, horses, dogs, skunks, pigs, mice, bovines, rats, and rabbits. None of the avian immunoglobulins bound to $\mathrm{SpG}$. Some of these interactions were confirmatory results as horse, pig, bovine and rabbit reactivity $[3,4]$.

SpL-SpL Sandwich ELISA: This ELISA is used to study the interaction of a protein-L (SpL) with different immunoglobulin preparations from various mammalian and avian species. The 96 well microtiter plate is coated overnight at $4^{\circ} \mathrm{C}$ with $2 \mu \mathrm{g} / \mu \mathrm{l}$ per well of SpL in carbonatebicarbonate buffer $\mathrm{pH}$ 9.6. Then plate is treated with bovine serum albumin solution and washed $4 \mathrm{X}$ with PBS-Tween. $50 \mu \mathrm{l}$ of immunoglobulins $(1 \mathrm{mg} / \mathrm{ml})$ is added and incubated for $1 \mathrm{~h}$ at room temperature and the microplate is rewashed $4 \mathrm{X}$ with PBS-Tween. Then, $50 \mu 1$ of peroxidaselabeled SpL conjugate diluted 1:5000 in PBS-non-fat milk is added to each well and incubated for $1 \mathrm{~h}$ at RT. The plate is washed $4 \mathrm{X}$ with PBS-Tween. $50 \mu \mathrm{l}$ of $4 \mathrm{mg} / \mathrm{ml}$ o-phenylenediamine solution (OPD) is added and the plate is incubated 15 minutes at RT in the dark. The reaction is stopped with $50 \mu \mathrm{l}$ of $3 \mathrm{M} \mathrm{H} 2 \mathrm{SO} 4$ solution. The plate is visually assessed for the development of colour and read in a microplate reader at $492 \mathrm{~nm}$. A cut-off point is calculated as the mean of the optical density of negative controls times two. The higher the OD value the higher will be the affinity of SpL to immunoglobulins. The cut-off point is 0.28 . 
Table 3. SpL-SpL Sandwich ELISA

\begin{tabular}{|l|c|c|c|c|}
\hline Immunoglobulins & XOD results & Binding affinity & $\begin{array}{l}\text { Coefficient of } \\
\text { variation (CV) } \\
\text { intra-assay (\%) }\end{array}$ & $\begin{array}{l}\text { CV inter-assay } \\
(\%)\end{array}$ \\
\hline Mule IgG & & & 2.97 & 3.56 \\
\hline Donkey IgG & 0.08 & - & 2.50 & 4.09 \\
\hline Horse IgG & 0.1 & - & 2.65 & 3.17 \\
\hline Dog IgG & 0.39 & - & 4.12 & 5.65 \\
\hline Skunk IgG & 0.13 & - & 2.46 & 5.10 \\
\hline Coyote IgG & 0.09 & - & 3.45 & 5.15 \\
\hline Raccoon IgG & 0.41 & + & 4.04 & 6.89 \\
\hline Ostrich IgY & 0.15 & - & 2.69 & 5.50 \\
\hline Pig IgG & 0.98 & +++ & 3.87 & 6.37 \\
\hline Mouse IgG & 1.07 & +++ & 2.48 & 4.98 \\
\hline Bovine IgG & 0.07 & - & 4.07 & 6.05 \\
\hline Rabbit IgG & 0.38 & + & 3.40 & 6.61 \\
\hline Chicken IgY & 0.14 & - & 2.61 & 4.05 \\
\hline Cat IgG & 0.11 & - & 3.06 & 4.98 \\
\hline Rat IgG & 0.09 & - & 2.78 & 3.95 \\
\hline
\end{tabular}

Table 3 shows SpL that interacts with fewer immunoglobulins than its counterpart SpA and SpG. IgGs from pigs and mice reacted strongly with SpL. Other species as dog, raccoon and rabbit reacted weakly $[5,7]$.

SpLG-SpLG Sandwich ELISA: This ELISA is used to study the interaction of a protein-LG (SpLG) with different immunoglobulin preparations from mammalian and avian species. The 96 well microtitre plate is coated overnight at $4^{\circ} \mathrm{C}$ with $2 \mu \mathrm{g} / \mu \mathrm{l}$ per well of a mixture of protein-L and protein-G in carbonate-bicarbonate buffer $\mathrm{pH}$ 9.6. Then plate is treated with bovine serum albumin solution and washed $4 \mathrm{X}$ with PBS-Tween. $50 \mu \mathrm{l}$ of immunoglobulins $(1 \mathrm{mg} / \mathrm{ml})$ is added and incubated for $1 \mathrm{~h}$ at room temperature and the microplate is rewashed $4 \mathrm{X}$ with PBSTween. Then $50 \mu 1$ of peroxidase-labeled SpLG conjugate diluted 1:5000 in PBS-non-fat milk is added to each well and incubated for $1 \mathrm{~h}$ at RT. The plate is washed $4 \mathrm{X}$ with PBS-Tween. $50 \mu \mathrm{l}$ of $4 \mathrm{mg} / \mathrm{ml}$ o-phenylenediamine solution (OPD) is added and the plate is incubated 15 minutes at $\mathrm{RT}$ in the dark. The reaction is stopped with $50 \mu \mathrm{l}$ of $3 \mathrm{M} \mathrm{H} 2 \mathrm{SO} 4$ solution. The plate is visually assessed for the development of colour and read in a microplate reader at $492 \mathrm{~nm}$. A cut-off point is calculated as the mean of the optical density of negative controls times two. The higher the OD value the higher will be the affinity of SpLG to molecules. The cut-off is 0.32 . 
Table 4. SpLG-SpLG Sandwich ELISA

\begin{tabular}{|l|c|c|c|c|}
\hline Immunoglobulins & XOD results & Binding affinity & $\begin{array}{l}\text { Coefficient of } \\
\text { variation (CV) } \\
\text { intra-assay }(\%)\end{array}$ & $\begin{array}{l}\text { CV inter-assay } \\
(\%)\end{array}$ \\
\hline Mule IgG & 0.95 & +++ & 4.65 & 7.85 \\
\hline Donkey IgG & 0.90 & +++ & 2.95 & 4.07 \\
\hline Horse IgG & 1.17 & +++ & 4.96 & 8.03 \\
\hline Dog IgG & $\mathbf{0 . 9 6}$ & +++ & 4.11 & 7.38 \\
\hline Skunk IgG & 1.13 & +++ & 4.52 & 7.48 \\
\hline Coyote IgG & 0.52 & + & 5.72 & 8.80 \\
\hline Raccoon IgG & 0.46 & + & 3.14 & 6.90 \\
\hline Ostrich IgY & 0.14 & - & 3.43 & 4.68 \\
\hline Pig IgG & 1.45 & +++ & 4.24 & 7.94 \\
\hline Mouse IgG & 1.39 & +++ & 3.77 & 5.09 \\
\hline Bovine IgG & 1.16 & +++ & 5.52 & 7.69 \\
\hline Rabbit IgG & 0.90 & +++ & 4.58 & 7.42 \\
\hline Chicken IgY & 0.16 & - & 2.95 & 4.41 \\
\hline Cat IgG & 0.11 & - & 3.84 & 5.00 \\
\hline Rat IgG & 1.60 & +++ & 4.98 & 7.06 \\
\hline
\end{tabular}

The SpLG conjugate used for the standardization of this immunoassay was prepared by mixing up SpL-HRP and SpG-HRP. It combines the binding affinities of both proteins. Table 4 depicts this assay, where IgGs from ten different species interacted strongly with SpLG. It did not react with cat $\operatorname{IgG}$ and chicken IgY but reacted weakly with IgGs from coyotes and raccoons.

SpLA-SpLA Sandwich ELISA: This ELISA is used to study the interaction of a protein-LA (SpLA) with different immunoglobulin preparations from mammalian and avian species. The 96 well microtitre plate is coated overnight at $4^{\circ} \mathrm{C}$ with $2 \mu \mathrm{g} / \mu \mathrm{l}$ per well of a mixture of protein-L and protein-A in carbonate-bicarbonate buffer $\mathrm{pH}$ 9.6. Then plate is treated with bovine serum albumin solution and washed $4 \mathrm{X}$ with PBS-Tween. $50 \mu \mathrm{l}$ of immunoglobulins $(1 \mathrm{mg} / \mathrm{ml})$ is added and incubated for $1 \mathrm{~h}$ at room temperature and the microplate is rewashed $4 \mathrm{X}$ with PBSTween. Then $50 \mu \mathrm{l}$ of peroxidase-labeled SpLA conjugate diluted 1:5000 in PBS-non-fat milk is added to each well and incubated for $1 \mathrm{~h}$ at RT. The plate is washed $4 \mathrm{X}$ with PBS-Tween. $50 \mu \mathrm{l}$ of $4 \mathrm{mg} / \mathrm{ml}$ o-phenylenediamine solution (OPD) is added and the plate is incubated 15 minutes at RT in the dark. The reaction is stopped with $50 \mu \mathrm{l}$ of $3 \mathrm{M} \mathrm{H} 2 \mathrm{SO} 4$ solution. The plate is visually assessed for the development of colour and read in a microplate reader at $492 \mathrm{~nm}$. A cut-off point is calculated as the mean of the optical density of negative controls times two. The higher the OD value the higher will be the affinity of SpLA to mammalian immunoglobulins. The cut-off point is 0.30 . 
Table 5. SpLA-SpLA Sandwich ELISA

\begin{tabular}{|l|c|c|c|c|}
\hline Immunoglobulins & XOD results & Binding affinity & $\begin{array}{l}\text { Coefficient of } \\
\text { variation (CV) } \\
\text { intra-assay (\%) }\end{array}$ & $\begin{array}{l}\text { CV inter-assay } \\
(\%)\end{array}$ \\
\hline Mule IgG & 0.44 & + & 3.14 & 5.46 \\
\hline Donkey IgG & 0.50 & + & 3.36 & 5.78 \\
\hline Horse IgG & 0.75 & ++ & 3.38 & 6.04 \\
\hline Dog IgG & 1.05 & +++ & 5.13 & 7.43 \\
\hline Skunk IgG & 1.01 & +++ & 3.50 & 6.41 \\
\hline Coyote IgG & 0.80 & ++ & 4.25 & 6.36 \\
\hline Raccoon IgG & 1.25 & +++ & 4.77 & 8.29 \\
\hline Ostrich IgY & 0.45 & + & 3.05 & 5.67 \\
\hline Pig IgG & 1.46 & +++ & 3.88 & 6.11 \\
\hline Mouse IgG & 1.50 & +++ & 4.08 & 6.95 \\
\hline Bovine IgG & 0.52 & + & 3.62 & 5.45 \\
\hline Rabbit IgG & 1.05 & +++ & 4.27 & 6.80 \\
\hline Chicken IgY & 0.15 & - & 3.30 & 4.04 \\
\hline Cat IgG & 1.05 & +++ & 3.75 & 6.02 \\
\hline Rat IgG & 0.50 & + & 2.96 & 4.63 \\
\hline
\end{tabular}

Table 5 depicts SpLA interacting strongly with a range of immunoglobulins. Very high affinity was detected between SpLA and IgGs from pigs, mice, and other few species.

SpAG-SpAG Sandwich ELISA: This ELISA is used to study the interaction of protein-AG (SpAG) with diverse immunoglobulins. The 96 well microtitre plate is coated overnight at $4{ }^{\circ} \mathrm{C}$ with $2 \mu \mathrm{g} / \mu \mathrm{l}$ per well of a mixture of SpA with $\mathrm{SpG}$ in carbonate-bicarbonate buffer $\mathrm{pH}$ 9.6. Then plate is treated with bovine serum albumin solution and washed $4 \mathrm{X}$ with PBS-Tween. $50 \mu 1$ of immunoglobulins $(1 \mathrm{mg} / \mathrm{ml})$ is added and incubated for $1.30 \mathrm{~h}$ at room temperature and the microplate is then rewashed $4 \mathrm{X}$ with PBS-Tween. Then $50 \mu 1$ of peroxidase-labeled-SpAG conjugate diluted 1:5000 in PBS-non-fat milk is added to each well and incubated for 1.30h at RT. After that, the plate is washed $4 X$ with PBS-Tween. Pipette $50 \mu \mathrm{l}$ of 3,3',5,5' -

tetramethylbenzidine (TMB; Sigma-Aldrich) to each well. The reaction is stopped with $50 \mu 1$ of $3 \mathrm{M} \mathrm{H} 2 \mathrm{SO} 4$ solution. The plate is visually assessed for the development of colour and read in a microplate reader at $450 \mathrm{~nm}$. A cut-off point is calculated as the mean of the optical density of negative controls times two. The higher the OD value the higher will be the binding affinity of SpAG to immunoglobulins. The cut-off point was 0.30 . 
Table 6. SpAG-SpAG Sandwich ELISA

\begin{tabular}{|l|c|c|c|c|}
\hline Immunoglobulins & XOD results & Binding affinity & $\begin{array}{l}\text { Coefficient of } \\
\text { variation }(\mathbf{C V}) \\
\text { intra-assay }(\%)\end{array}$ & $\begin{array}{l}\text { CV inter-assay } \\
(\%)\end{array}$ \\
\hline Mule IgG & $\mathbf{0 . 9 2}$ & +++ & 3.78 & 6.74 \\
\hline Donkey IgG & 1.05 & +++ & 2.64 & 5.30 \\
\hline Horse IgG & 0.95 & +++ & 4.15 & 7.85 \\
\hline Dog IgG & 1.26 & +++ & 3.94 & 5.71 \\
\hline Skunk IgG & 1.24 & +++ & 3.29 & 4.78 \\
\hline Coyote IgG & 0.99 & +++ & 3.88 & 6.67 \\
\hline Raccoon IgG & 0.95 & +++ & 5.16 & $\mathbf{8 . 7 7}$ \\
\hline Ostrich IgY & $\mathbf{0 . 4 5}$ & + & 2.42 & 3.21 \\
\hline Pig IgG & 1.43 & +++ & 3.89 & 6.60 \\
\hline Mouse IgG & 1.41 & +++ & 2.67 & 4.79 \\
\hline Bovine IgG & 1.14 & +++ & 3.35 & 5.16 \\
\hline Rabbit IgG & 1.33 & +++ & 4.38 & 6.84 \\
\hline Chicken IgY & 0.15 & - & 2.96 & 4.43 \\
\hline Cat IgG & 1.34 & +++ & 3.17 & 4.83 \\
\hline Rat IgG & 1.10 & +++ & 2.89 & 5.01 \\
\hline
\end{tabular}

Table 6 shows that SpAG is a versatile protein, which reacted strongly with 13 out of 15 IgGs. It reacted strongly with the $86.6 \%$ of the Ig panel.

SpA and SpLA sandwich ELISA: This ELISA is used to study the interactions between Staphylococcal protein-A (SpA) and protein-LA (SpLA) with different immunoglobulin preparations from mammalian and avian species. The 96 well microtitre plate is coated overnight at $4{ }^{\circ} \mathrm{C}$ with $2 \mu \mathrm{g} / \mu \mathrm{l}$ per well of SpA in carbonate-bicarbonate buffer $\mathrm{pH}$ 9.6. Then plate is treated with bovine serum albumin solution and washed $4 \mathrm{X}$ with PBS-Tween. $50 \mu \mathrm{l}$ of immunoglobulins $(1 \mathrm{mg} / \mathrm{ml})$ is added and incubated for $1 \mathrm{~h}$ at room temperature and the microplate is rewashed $4 \mathrm{X}$ with PBS-Tween. Then $50 \mu 1$ of peroxidase-labeled SpLA conjugate diluted 1:5000 in PBS-nonfat milk is added to each well and incubated for $1 \mathrm{~h}$ at RT. The plate is washed $4 \mathrm{X}$ with PBSTween. $50 \mu 1$ of $4 \mathrm{mg} / \mathrm{ml}$ o-phenylenediamine solution (OPD) is added and the plate is incubated 15 minutes at RT in the dark. The reaction is stopped with $50 \mu 1$ of $3 \mathrm{M} \mathrm{H} 2 \mathrm{SO} 4$ solution. The plate is visually assessed for the development of colour and read in a microplate reader at 492 $\mathrm{nm}$. The cut-off point is 0.32 . 
Table 7. SpA and SpLA sandwich ELISA.

\begin{tabular}{|l|c|c|c|c|}
\hline Immunoglobulins & XOD results & Binding affinity & $\begin{array}{l}\text { Coefficient of } \\
\text { variation (CV) } \\
\text { intra-assay }(\%)\end{array}$ & $\begin{array}{l}\text { CV inter-assay } \\
(\%)\end{array}$ \\
\hline Mule IgG & 0.45 & + & 2.53 & 4.44 \\
\hline Donkey IgG & 0.55 & + & 4.89 & 6.35 \\
\hline Horse IgG & $\mathbf{0 . 6 8}$ & ++ & 3.67 & 5.38 \\
\hline Dog IgG & 1.40 & +++ & 3.03 & 4.71 \\
\hline Skunk IgG & 1.21 & +++ & 2.28 & 4.11 \\
\hline Coyote IgG & 0.75 & ++ & 4.18 & 7.09 \\
\hline Raccoon IgG & 1.47 & +++ & 4.26 & 4.75 \\
\hline Ostrich IgY & 0.53 & + & 3.30 & 9.68 \\
\hline Pig IgG & 1.50 & +++ & 4.14 & 7.47 \\
\hline Mouse IgG & 1.59 & +++ & 2.27 & 4.03 \\
\hline Bovine IgG & $\mathbf{0 . 7 0}$ & ++ & 3.54 & 4.15 \\
\hline Rabbit IgG & 1.05 & +++ & 2.73 & 4.02 \\
\hline Chicken IgY & 0.16 & - & 2.30 & 3.89 \\
\hline Cat IgG & 1.45 & +++ & 3.36 & 5.70 \\
\hline Rat IgG & 0.53 & + & 4.09 & 6.83 \\
\hline
\end{tabular}

Table 7 depicts a hybrid ELISA that demonstrates the binding affinity of both SpA and SpLA. $\mathrm{IgG}$ in this ELISA are more likely to interact with SpA. As demonstrated in previous ELISA the binding affinity of SpA surpasses that of SpL. IgGs from dogs, skunks, pigs, mice, rabbits, and cats reacted strongly with SpA. But pig and mouse immunoglobulins had the highest binding affinities since they are capable of strongly reacting to both SpA and SpL. There is a report of the creation of a versatile hybrid recombinant SpLA [29].

SpA and SpLG sandwich ELISA: This ELISA is used to study the interactions between Staphylococcal protein-A (SpA) and protein-LG (SpLG) with different immunoglobulin preparations from mammalian and avian species. The 96 well microtitre plate is coated overnight at $4{ }^{\circ} \mathrm{C}$ with $2 \mu \mathrm{g} / \mu \mathrm{l}$ per well of SpA in carbonate-bicarbonate buffer $\mathrm{pH}$ 9.6. Then plate is treated with bovine serum albumin solution and washed $4 \mathrm{X}$ with PBS-Tween. $50 \mu \mathrm{l}$ of immunoglobulins $(1 \mathrm{mg} / \mathrm{ml})$ is added and incubated for $1 \mathrm{~h}$ at room temperature and the microplate is rewashed $4 \mathrm{X}$ with PBS-Tween. Then $50 \mu$ l of peroxidase-labeled SpLG conjugate diluted 1:5000 in PBS-nonfat milk is added to each well and incubated for $1 \mathrm{~h}$ at RT. The plate is washed $4 \mathrm{X}$ with PBSTween. $50 \mu 1$ of $4 \mathrm{mg} / \mathrm{ml}$ o-phenylenediamine solution (OPD) is added and the plate is incubated 15 minutes at RT in the dark. The reaction is stopped with $50 \mu \mathrm{l}$ of $3 \mathrm{M} \mathrm{H} 2 \mathrm{SO} 4$ solution. The plate is visually assessed for the development of colour and read in a microplate reader at 492 $\mathrm{nm}$. A cut-off point is calculated as the mean of the optical density of negative controls times two. The cut-off point was 0.32 . 
Table 8. SpA and SpLG sandwich ELISA

\begin{tabular}{|l|c|c|c|c|}
\hline Immunoglobulins & XOD results & Binding affinity & $\begin{array}{l}\text { Coefficient of } \\
\text { variation (CV) } \\
\text { intra-assay }(\%)\end{array}$ & $\begin{array}{l}\text { CV inter-assay } \\
(\%)\end{array}$ \\
\hline Mule IgG & 1.25 & +++ & 3.67 & 6.95 \\
\hline Donkey IgG & 1.02 & +++ & 4.08 & 8.05 \\
\hline Horse IgG & 1.37 & +++ & 3.85 & 5.24 \\
\hline Dog IgG & 1.45 & +++ & 3.95 & 6.00 \\
\hline Skunk IgG & 1.23 & +++ & 4.74 & 6.25 \\
\hline Coyote IgG & 0.47 & + & 3.89 & 5.97 \\
\hline Raccoon IgG & 1.30 & +++ & 2.96 & 4.75 \\
\hline Ostrich IgY & 0.52 & + & 4.55 & 5.90 \\
\hline Pig IgG & 1.05 & +++ & 3.06 & 6.66 \\
\hline Mouse IgG & 1.37 & +++ & 4.50 & 7.57 \\
\hline Bovine IgG & $\mathbf{0 . 7 0}$ & ++ & 6.01 & 9.28 \\
\hline Rabbit IgG & 1.15 & +++ & 4.07 & 6.37 \\
\hline Chicken IgY & 0.16 & - & 4.98 & 8.05 \\
\hline Cat IgG & 0.46 & + & 4.82 & 7.42 \\
\hline Rat IgG & 1.40 & +++ & 5.86 & 9.23 \\
\hline
\end{tabular}

Table 8 shows a type of immunoassay, where immunoglobulins serve as a bridge between two different bacterial proteins. SpA and SpLG react strongly with equine Igs, and IgGs of dogs, skunks, raccoons, pigs, mice, rabbits, and rats. It did not react with chicken $\operatorname{IgY}$, which in fact is the negative control used to calculate the cut-off point.

Table 9. SpA and SpAG sandwich ELISA: This ELISA is used to study the interactions between Staphylococcal protein-A (SpA) and protein-AG (SpAG) with different immunoglobulin preparations from mammalian and avian species. The 96 well microtitre plate is coated overnight at $4^{\circ} \mathrm{C}$ with $2 \mu \mathrm{g} / \mu \mathrm{l}$ per well of SpA in carbonate-bicarbonate buffer $\mathrm{pH}$ 9.6. Then plate is treated with bovine serum albumin solution and washed $4 \mathrm{X}$ with PBS-Tween. $50 \mu 1$ of immunoglobulins $(1 \mathrm{mg} / \mathrm{ml})$ is added and incubated for $1 \mathrm{~h}$ at room temperature and the microplate is rewashed $4 \mathrm{X}$ with PBS-Tween. Then $50 \mu 1$ of peroxidase-labeled SpAG conjugate diluted 1:5000 in PBS-non-fat milk is added to each well and incubated for $1 \mathrm{~h}$ at RT. The plate is washed $4 \mathrm{X}$ with PBS-Tween. $50 \mu \mathrm{l}$ of $4 \mathrm{mg} / \mathrm{ml}$ o-phenylenediamine solution is added and the plate is incubated 15 minutes at RT in the dark. The reaction is stopped with $50 \mu 1$ of 3M H2SO4 solution. The plate is visually assessed for the development of colour and read in a microplate reader at $492 \mathrm{~nm}$. A cut-off point is calculated as the mean of the optical density of negative controls times two. The cut-off point is 0.34 . 
SpA and SpAG sandwich ELISA

\begin{tabular}{|l|c|c|c|c|}
\hline Immunoglobulins & XOD results & Binding affinity & $\begin{array}{l}\text { Coefficient of } \\
\text { variation (CV) } \\
\text { intra-assay }(\%)\end{array}$ & $\begin{array}{l}\text { CV inter-assay } \\
(\%)\end{array}$ \\
\hline Mule IgG & 1.18 & +++18 & 7.28 \\
\hline Donkey IgG & 1.26 & +++ & 3.78 & 5.95 \\
\hline Horse IgG & 1.42 & +++ & 3.06 & 5.70 \\
\hline Dog IgG & 1.60 & +++ & 2.79 & 4.86 \\
\hline Skunk IgG & 1.33 & +++ & 4.05 & 6.37 \\
\hline Coyote IgG & 1.20 & +++ & 3.80 & 6.21 \\
\hline Raccoon IgG & 1.15 & +++ & 3.68 & 5.07 \\
\hline Ostrich IgY & 0.49 & + & 4.86 & 7.10 \\
\hline Pig IgG & 1.67 & +++ & 2.96 & 4.97 \\
\hline Mouse IgG & 1.57 & +++ & 4.00 & 7.67 \\
\hline Bovine IgG & 1.08 & +++ & 4.29 & 7.42 \\
\hline Rabbit IgG & 1.24 & +++ & 4.76 & 6.60 \\
\hline Chicken IgY & 0.17 & - & 3.50 & 5.73 \\
\hline Cat IgG & 1.13 & +++ & 3.79 & 6.01 \\
\hline Rat IgG & 0.48 & + & 4.86 & 6.52 \\
\hline
\end{tabular}

Table 9 depicts immunoglobulins reacting strongly with SpA and SpAG. In this assay, except ostrich IgY and IgGs from rats interacted with the immunoglobulin-binding protein.

SpG and SpLA sandwich ELISA: This ELISA is used to study the interactions between Staphylococcal protein-G (SpG) and protein-LA (SpLA) with different immunoglobulin preparations from mammalian and avian species. The 96 well microtitre plate is coated overnight at $4{ }^{\circ} \mathrm{C}$ with $2 \mu \mathrm{g} / \mu \mathrm{l}$ per well of $\mathrm{SpG}$ in carbonate-bicarbonate buffer $\mathrm{pH}$ 9.6. Then plate is treated with bovine serum albumin solution and washed $4 \mathrm{X}$ with PBS-Tween. $50 \mu \mathrm{l}$ of immunoglobulins $(1 \mathrm{mg} / \mathrm{ml})$ is added and incubated for $1 \mathrm{~h}$ at room temperature and the microplate is rewashed $4 \mathrm{X}$ with PBS-Tween. Then $50 \mu$ l of peroxidase-labeled SpLA conjugate diluted 1:5000 in PBS-nonfat milk is added to each well and incubated for $1 \mathrm{~h}$ at RT. The plate is washed $4 \mathrm{X}$ with PBSTween. $50 \mu 1$ of $4 \mathrm{mg} / \mathrm{ml}$ o-phenylenediamine solution (OPD) is added and the plate is incubated 15 minutes at RT in the dark. The reaction is stopped with $50 \mu 1$ of $3 \mathrm{M} \mathrm{H} 2 \mathrm{SO} 4$ solution. The plate is visually assessed for the development of colour and read in a microplate reader at 492 $\mathrm{nm}$. A cut-off point is calculated as the mean of the optical density of negative controls times two. The cut-off point is 0.36 . 
Table 10. SpG and SpLA sandwich ELISA

\begin{tabular}{|l|c|c|c|c|}
\hline Immunoglobulins & XOD results & Binding affinity & $\begin{array}{l}\text { Coefficient of } \\
\text { variation }(\mathbf{C V}) \\
\text { intra-assay }(\%)\end{array}$ & $\begin{array}{l}\text { CV inter-assay } \\
(\%) .78\end{array}$ \\
\hline Mule IgG & 1.15 & +++ & 3.27 & 7.28 \\
\hline Donkey IgG & 1.24 & +++ & 3.86 & 6.04 \\
\hline Horse IgG & 1.17 & +++ & 3.56 & 5.86 \\
\hline Dog IgG & 1.48 & +++ & 3.60 & 5.80 \\
\hline Skunk IgG & 1.20 & +++ & 3.09 & 5.94 \\
\hline Coyote IgG & $\mathbf{0 . 9 3}$ & +++ & 4.86 & 7.04 \\
\hline Raccoon IgG & 1.04 & +++ & 4.06 & 7.96 \\
\hline Ostrich IgY & 0.65 & ++ & 3.75 & 6.87 \\
\hline Pig IgG & 1.55 & +++ & 3.75 & 5.80 \\
\hline Mouse IgG & 1.68 & +++ & 4.38 & 6.03 \\
\hline Bovine IgG & 0.70 & ++ & 4.47 & 6.78 \\
\hline Rabbit IgG & 1.32 & +++ & 3.21 & 5.27 \\
\hline Chicken IgY & 0.18 & - & 4.81 & 8.08 \\
\hline Cat IgG & 0.37 & + & 3.44 & 6.80 \\
\hline Rat IgG & 0.52 & + & 3.86 & 5.11 \\
\hline
\end{tabular}

In this immunoassay both SpG and SpLA react with the entire panel of immunoglobulins as shown in Table 10. All IgGs react effectively with both bacterial protein except cat and rat IgGs that reacted weakly.

SpG and SpLG sandwich ELISA: This ELISA is used to study the interactions between Staphylococcal protein-G (SpG) and protein-LG (SpLG) with different immunoglobulin preparations from mammalian and avian species. The 96 well microtitre plate is coated overnight at $4^{\circ} \mathrm{C}$ with $2 \mu \mathrm{g} / \mu \mathrm{l}$ per well of $\mathrm{SpG}$ in carbonate-bicarbonate buffer $\mathrm{pH}$ 9.6. Then plate is treated with bovine serum albumin solution and washed $4 \mathrm{X}$ with PBS-Tween. $50 \mu \mathrm{l}$ of immunoglobulins $(1 \mathrm{mg} / \mathrm{ml})$ is added and incubated for $1 \mathrm{~h}$ at room temperature and the microplate is rewashed $4 \mathrm{X}$ with PBS-Tween. Then $50 \mu$ l of peroxidase-labeled SpLG conjugate diluted 1:5000 in PBS-nonfat milk is added to each well and incubated for $1 \mathrm{~h}$ at RT. The plate is washed $4 \mathrm{X}$ with PBSTween. $50 \mu \mathrm{l}$ of $4 \mathrm{mg} / \mathrm{ml}$ o-phenylenediamine solution (OPD) is added and the plate is incubated 15 minutes at RT in the dark. The reaction is stopped with $50 \mu 1$ of $3 \mathrm{M} \mathrm{H} 2 \mathrm{SO} 4$ solution. The plate is visually assessed for the development of colour and read in a microplate reader at 492 $\mathrm{nm}$. A cut-off point is calculated as the mean of the optical density of negative controls times two. The cut-off point is 0.36 . 
Table 11. SpG and SpLG sandwich ELISA

\begin{tabular}{|l|c|c|c|c|}
\hline Immunoglobulins & XOD results & Binding affinity & $\begin{array}{l}\text { Coefficient of } \\
\text { variation (CV) } \\
\text { intra-assay }(\%)\end{array}$ & $\begin{array}{l}\text { CV inter-assay } \\
(\%)\end{array}$ \\
\hline Mule IgG & 1.25 & +++ & 2.68 & 5.08 \\
\hline Donkey IgG & 1.14 & +++ & 2.95 & 4.86 \\
\hline Horse IgG & 1.30 & +++ & 3.15 & 5.76 \\
\hline Dog IgG & 1.53 & +++ & 2.69 & 5.06 \\
\hline Skunk IgG & 1.13 & +++ & 3.09 & 6.20 \\
\hline Coyote IgG & 0.75 & ++ & 2.96 & 4.16 \\
\hline Raccoon IgG & 0.42 & + & 4.52 & 8.15 \\
\hline Ostrich IgY & 0.51 & + & 3.89 & 7.02 \\
\hline Pig IgG & 1.38 & +++ & 4.34 & 6.70 \\
\hline Mouse IgG & 1.35 & +++ & 3.66 & 5.81 \\
\hline Bovine IgG & 1.05 & +++ & 4.01 & 6.22 \\
\hline Rabbit IgG & 1.42 & +++ & 5.15 & 7.88 \\
\hline Chicken IgY & 0.18 & - & 2.96 & 4.28 \\
\hline Cat IgG & 0.25 & - & 4.75 & 8.10 \\
\hline Rat IgG & 0.75 & ++ & 2.97 & 5.09 \\
\hline
\end{tabular}

In the SpG-SpLG ELISA, IgGs from equines, dogs, skunks, pigs, mice, bovines, and rabbits strongly bound to both bacterial proteins as shown in Table 11. However, cat IgG was below the cut-off point.

SpG and SpAG sandwich ELISA: This ELISA is used to study the interactions between Staphylococcal protein-G (SpG) and protein-AG (SpAG) with different immunoglobulin preparations from mammalian and avian species. The 96 well microtitre plate is coated overnight at $4^{\circ} \mathrm{C}$ with $2 \mu \mathrm{g} / \mu \mathrm{l}$ per well of $\mathrm{SpG}$ in carbonate-bicarbonate buffer $\mathrm{pH}$ 9.6. Then plate is treated with bovine serum albumin solution and washed $4 \mathrm{X}$ with PBS-Tween. $50 \mu \mathrm{l}$ of immunoglobulins $(1 \mathrm{mg} / \mathrm{ml})$ is added and incubated for $1 \mathrm{~h}$ at room temperature and the microplate is rewashed $4 \mathrm{X}$ with PBS-Tween. Then 50 $\mu$ l of peroxidase-labeled SpAG conjugate diluted 1:5000 in PBS-nonfat milk is added to each well and incubated for $1 \mathrm{~h}$ at RT. The plate is washed $4 \mathrm{X}$ with PBSTween. $50 \mu \mathrm{l}$ of $4 \mathrm{mg} / \mathrm{ml}$ o-phenylenediamine solution (OPD) is added and the plate is incubated 15 minutes at RT in the dark. The reaction is stopped with $50 \mu 1$ of $3 \mathrm{M} \mathrm{H} 2 \mathrm{SO} 4$ solution. The plate is visually assessed for the development of colour and read in a microplate reader at 492 $\mathrm{nm}$. A cut-off point is calculated as the mean of the optical density of negative controls times two. The cut-off point is 0.32 . 
Table 12. SpG and SpAG sandwich ELISA

\begin{tabular}{|l|c|c|c|c|}
\hline Immunoglobulins & XOD results & Binding affinity & $\begin{array}{l}\text { Coefficient of } \\
\text { variation }(\mathbf{C V}) \\
\text { intra-assay }(\%)\end{array}$ & $\begin{array}{l}\text { CV inter-assay } \\
(\%)\end{array}$ \\
\hline Mule IgG & $\mathbf{0 . 9 8}$ & +++ & 4.13 & 7.58 \\
\hline Donkey IgG & 1.03 & +++ & 3.60 & 6.26 \\
\hline Horse IgG & 1.25 & +++ & 4.15 & 7.05 \\
\hline Dog IgG & 1.31 & +++ & 3.22 & 5.46 \\
\hline Skunk IgG & 1.37 & +++ & 4.14 & 7.05 \\
\hline Coyote IgG & 0.75 & ++ & 2.89 & 5.27 \\
\hline Raccoon IgG & 0.87 & ++ & 3.65 & 5.08 \\
\hline Ostrich IgY & 0.52 & + & 3.49 & 5.75 \\
\hline Pig IgG & 1.35 & +++ & 4.06 & 6.35 \\
\hline Mouse IgG & 1.40 & +++ & 4.18 & 7.25 \\
\hline Bovine IgG & 1.17 & +++ & 3.79 & 7.17 \\
\hline Rabbit IgG & 1.23 & +++ & 3.88 & 6.70 \\
\hline Chicken IgY & 0.16 & - & 3.05 & 5.12 \\
\hline Cat IgG & 0.36 & + & 4.85 & $\mathbf{8 . 1 9}$ \\
\hline Rat IgG & 0.70 & ++ & 3.45 & 6.67 \\
\hline
\end{tabular}

The cat IgG binds weakly to SpG. Some authors have shown no reactivity at all [6]. However, the panel of 35 ELISAs in this study assure a 1+ binding between cat IgG and SpG. On the other hand, SpG and SpAG strongly interact with IgGs from much species including mule, donkey, dog, skunk, pig, and others as shown in Table 12.

SpL and SpAG sandwich ELISA: This ELISA is used to study the interactions between Staphylococcal protein-L (SpL) and protein-AG with different immunoglobulin preparations from mammalian and avian species. The 96 well microtitre plate is coated overnight at $4{ }^{\circ} \mathrm{C}$ with $2 \mu \mathrm{g} / \mu 1$ per well of $\mathrm{SpL}$ in carbonate-bicarbonate buffer $\mathrm{pH}$ 9.6. Then plate is treated with bovine serum albumin solution and washed $4 \mathrm{X}$ with PBS-Tween. $50 \mu \mathrm{l}$ of immunoglobulins $(1 \mathrm{mg} / \mathrm{ml})$ is added and incubated for $1 \mathrm{~h}$ at room temperature and the microplate is rewashed $4 \mathrm{X}$ with PBSTween. Then, $50 \mu$ l of peroxidase-labeled SpAG conjugate diluted 1:5000 in PBS-non-fat milk is added to each well and incubated for $1 \mathrm{~h}$ at RT. The plate is washed $4 \mathrm{X}$ with PBS-Tween. $50 \mu \mathrm{l}$ of $4 \mathrm{mg} / \mathrm{ml}$ o-phenylenediamine solution (OPD) is added and the plate is incubated 15 minutes at RT in the dark. The reaction is stopped with $50 \mu 1$ of $3 \mathrm{M} \mathrm{H} 2 \mathrm{SO} 4$ solution. The plate is visually assessed for the development of colour and read in a microplate reader at $492 \mathrm{~nm}$. A cut-off point is calculated as the mean of the optical density of negative controls times two. The cut-off point was 0.28 . 
Table 13. SpL and SpAG sandwich ELISA

\begin{tabular}{|l|c|c|c|c|}
\hline Immunoglobulins & XOD results & Binding affinity & $\begin{array}{l}\text { Coefficient of } \\
\text { variation (CV) } \\
\text { intra-assay (\%) }\end{array}$ & $\begin{array}{l}\text { CV inter-assay } \\
(\%)\end{array}$ \\
\hline Mule IgG & 0.1 & - & 2.85 & 4.50 \\
\hline Donkey IgG & 0.08 & - & 2.46 & 3.07 \\
\hline Horse IgG & $\mathbf{0 . 1 1}$ & - & 3.15 & 4.84 \\
\hline Dog IgG & $\mathbf{0 . 4 1}$ & + & 4.12 & 5.61 \\
\hline Skunk IgG & 0.11 & - & 3.46 & 4.53 \\
\hline Coyote IgG & 0.09 & - & 2.45 & 3.94 \\
\hline Raccoon IgG & 0.42 & + & 3.46 & 5.83 \\
\hline Ostrich IgY & 0.18 & - & 2.96 & 4.40 \\
\hline Pig IgG & 1.15 & +++ & 3.80 & 5.06 \\
\hline Mouse IgG & 1.12 & +++ & 2.48 & 3.98 \\
\hline Bovine IgG & $\mathbf{0 . 0 9}$ & - & 2.77 & 5.57 \\
\hline Rabbit IgG & 0.34 & + & 3.43 & 5.60 \\
\hline Chicken IgY & 0.14 & - & 2.10 & 4.56 \\
\hline Cat IgG & 0.10 & - & 2.51 & 3.90 \\
\hline Rat IgG & 0.01 & - & 3.01 & 4.96 \\
\hline
\end{tabular}

In this ELISA depicted in Table 13, the 3 bacterial proteins have the capacity to react strongly with IgGs from several species including pig, skunk, and dog. Immunoglobulins from ten different animal species were below the cut-off point.

SpL and SpLG sandwich ELISA: This ELISA is used to study the interactions between Staphylococcal protein-L (SpL) and protein-LG with different immunoglobulin preparations from mammalian and avian species. The 96 well microtitre plate is coated overnight at $4{ }^{\circ} \mathrm{C}$ with $2 \mu \mathrm{g} / \mu \mathrm{l}$ per well of SpL in carbonate-bicarbonate buffer $\mathrm{pH}$ 9.6. Then plate is treated with bovine serum albumin solution and washed $4 \mathrm{X}$ with PBS-Tween. $50 \mu \mathrm{l}$ of immunoglobulins $(1 \mathrm{mg} / \mathrm{ml})$ is added and incubated for $1 \mathrm{~h}$ at room temperature and the microplate is rewashed $4 \mathrm{X}$ with PBSTween. Then, $50 \mu 1$ of peroxidase-labeled SpLG conjugate diluted 1:5000 in PBS-non-fat milk is added to each well and incubated for $1 \mathrm{~h}$ at RT. The plate is washed $4 \mathrm{X}$ with PBS-Tween. $50 \mu \mathrm{l}$ of $4 \mathrm{mg} / \mathrm{ml}$ o-phenylenediamine solution (OPD) is added and the plate is incubated 15 minutes at $\mathrm{RT}$ in the dark. The reaction is stopped with $50 \mu \mathrm{l}$ of $3 \mathrm{M} \mathrm{H} 2 \mathrm{SO} 4$ solution. The plate is visually assessed for the development of colour and read in a microplate reader at $492 \mathrm{~nm}$. A cut-off point is calculated as the mean of the optical density of negative controls times two. The cut-off point was 0.32 . 
Table 14. SpL and SpLG sandwich ELISA

\begin{tabular}{|l|c|c|c|c|}
\hline Immunoglobulins & XOD results & Binding affinity & $\begin{array}{l}\text { Coefficient of } \\
\text { variation (CV) } \\
\text { intra-assay (\%) }\end{array}$ & $\begin{array}{l}\text { CV inter-assay } \\
(\%)\end{array}$ \\
\hline Mule IgG & 0.15 & - & 3.85 & 5.50 \\
\hline Donkey IgG & 0.12 & - & 3.46 & 4.00 \\
\hline Horse IgG & 0.17 & - & 2.25 & 3.73 \\
\hline Dog IgG & 0.38 & + & 3.30 & 4.68 \\
\hline Skunk IgG & 0.20 & - & 4.01 & 7.55 \\
\hline Coyote IgG & 0.15 & - & 2.65 & 5.04 \\
\hline Raccoon IgG & 0.40 & + & 4.76 & 9.83 \\
\hline Ostrich IgY & 0.21 & - & 3.28 & 4.50 \\
\hline Pig IgG & 0.95 & +++ & 3.80 & 6.43 \\
\hline Mouse IgG & 1.06 & +++ & 4.47 & 7.98 \\
\hline Bovine IgG & 0.11 & - & 3.77 & 4.97 \\
\hline Rabbit IgG & 0.41 & + & 4.43 & 6.10 \\
\hline Chicken IgY & 0.16 & - & 3.10 & 4.26 \\
\hline Cat IgG & 0.14 & - & 4.08 & 6.20 \\
\hline Rat IgG & 0.09 & - & 2.65 & 4.25 \\
\hline
\end{tabular}

In this immunoassay only some species bind to the solid phase since the binding of SpL to immunoglobulins is limited as compared of that of SpA and SpG. AS shown in Table 14 only pig and mouse IgGs interact strongly with the bacterial receptors (SpL and SpLG).

SpL and SpLA sandwich ELISA: This ELISA is used to study the interactions between protein-L (SpL) and protein-LA (SpLA) with different immunoglobulin preparations from mammalian and avian species. The 96 well microtitre plate is coated overnight at $4{ }^{\circ} \mathrm{C}$ with 2 $\mu \mathrm{g} / \mu \mathrm{l}$ per well of SpL in carbonate-bicarbonate buffer $\mathrm{pH} 9.6$. Then plate is treated with bovine serum albumin solution and washed $4 \mathrm{X}$ with PBS-Tween. $50 \mu \mathrm{l}$ of immunoglobulins $(1 \mathrm{mg} / \mathrm{ml})$ is added and incubated for $1 \mathrm{~h}$ at room temperature (RT) and the microplate is rewashed $4 \mathrm{X}$ with PBS-Tween. Then $50 \mu 1$ of peroxidase-labeled SpLA conjugate diluted 1:5000 in PBS-non-fat milk is added to each well and incubated for $1 \mathrm{~h}$ at RT. The plate is washed $4 \mathrm{X}$ with PBS-Tween. $50 \mu 1$ of $4 \mathrm{mg} / \mathrm{ml}$ o-phenylenediamine solution (OPD) is added and the plate is incubated 15 minutes at RT in the for the development of colour and read in a microplate reader at $492 \mathrm{~nm}$. A cut-off point is calculated as the mean of the optical density of negative controls times two. The cut-off point is 0.26 . 
Table 15. SpL and SpLA sandwich ELISA

\begin{tabular}{|l|c|c|c|c|}
\hline Immunoglobulins & XOD results & Binding affinity & $\begin{array}{l}\text { Coefficient of } \\
\text { variation (CV) } \\
\text { intra-assay (\%) }\end{array}$ & $\begin{array}{l}\text { CV inter-assay } \\
(\%)\end{array}$ \\
\hline Mule IgG & 0.15 & - & 3.85 & 5.50 \\
\hline Donkey IgG & 0.12 & - & 3.46 & 4.00 \\
\hline Horse IgG & 0.17 & - & 2.25 & 3.73 \\
\hline Dog IgG & 0.38 & + & 3.30 & 4.68 \\
\hline Skunk IgG & 0.20 & - & 4.01 & 7.55 \\
\hline Coyote IgG & 0.15 & - & 2.65 & 5.04 \\
\hline Raccoon IgG & 0.40 & + & 4.76 & 9.83 \\
\hline Ostrich IgY & 0.20 & - & 3.28 & 4.50 \\
\hline Pig IgG & 0.95 & +++ & 3.80 & 6.43 \\
\hline Mouse IgG & 1.06 & +++ & 4.47 & 7.98 \\
\hline Bovine IgG & 0.11 & - & 3.77 & 4.97 \\
\hline Rabbit IgG & 0.41 & + & 4.43 & 6.10 \\
\hline Chicken IgY & 0.13 & - & 3.10 & 4.26 \\
\hline Cat IgG & 0.14 & - & 2.33 & 3.78 \\
\hline Rat IgG & 0.18 & - & 2.86 & 3.90 \\
\hline
\end{tabular}

This immunoassay like the just above characterizes by fewer interactions between the bacterial immunoglobulin-binding proteins and IgGs. Table 15 depicts the SpL-SpLA sandwich ELISA, where $\mathrm{SpL}$ does not react with immunoglobulins from species of donkey, horse, mule, skunk, ostrich, bovine, cat, and rat. It suggests that SpL may not be suitable for certain assays, such as the study of the presence of antibodies against certain zoonotic pathogens in a greater number of animals in a population [10].

SpA and PLAG sandwich ELISA: This ELISA is used to study the interactions between Staphylococcal protein-A (SpA) and protein-LAG (PLAG) with different immunoglobulin preparations from mammalian and avian species. The 96 well microtitre plate is coated overnight at $4{ }^{\circ} \mathrm{C}$ with $2 \mu \mathrm{g} / \mu \mathrm{l}$ per well of SpA in carbonate-bicarbonate buffer $\mathrm{pH}$ 9.6. Then plate is treated with bovine serum albumin solution and washed $4 \mathrm{X}$ with PBS-Tween. $50 \mu \mathrm{l}$ of immunoglobulins $(1 \mathrm{mg} / \mathrm{ml})$ is added and incubated for $1 \mathrm{~h}$ at room temperature and the microplate is rewashed $4 \mathrm{X}$ with PBS-Tween. Then $50 \mu$ l of peroxidase-labeled PLAG conjugate diluted 1:5000 in PBS-nonfat milk is added to each well and incubated for $1 \mathrm{~h}$ at RT. The plate is washed $4 \mathrm{X}$ with PBSTween. $50 \mu 1$ of $4 \mathrm{mg} / \mathrm{ml}$ o-phenylenediamine solution (OPD) is added and the plate is incubated 15 minutes at RT in the dark. The reaction is stopped with $50 \mu \mathrm{l}$ of $3 \mathrm{M} \mathrm{H} 2 \mathrm{SO} 4$ solution. The plate is visually assessed for the development of colour and read in a microplate reader at 492 $\mathrm{nm}$. A cut-off point is calculated as the mean of the optical density of negative controls times two. The cut-off point is 0.32 . 
Table 16. SpA and PLAG sandwich ELISA

\begin{tabular}{|l|c|c|c|c|}
\hline Immunoglobulins & XOD results & Binding affinity & $\begin{array}{l}\text { Coefficient of } \\
\text { variation }(\mathbf{C V}) \\
\text { intra-assay }(\%)\end{array}$ & $\begin{array}{l}\text { CV inter-assay } \\
(\%)\end{array}$ \\
\hline Mule IgG & $\mathbf{0 . 7 6}$ & ++ & 4.18 & 7.28 \\
\hline Donkey IgG & 0.80 & ++ & 3.78 & 5.95 \\
\hline Horse IgG & 0.78 & ++ & 3.06 & 5.70 \\
\hline Dog IgG & 1.10 & +++ & 2.79 & 4.86 \\
\hline Skunk IgG & 1.25 & +++ & 4.05 & 6.37 \\
\hline Coyote IgG & 1.19 & +++ & 3.80 & 6.21 \\
\hline Raccoon IgG & 1.30 & +++ & 3.68 & 5.07 \\
\hline Ostrich IgY & 0.53 & + & 4.86 & 7.10 \\
\hline Pig IgG & 1.37 & +++ & 2.96 & 4.97 \\
\hline Mouse IgG & 1.39 & +++ & 4.00 & 7.67 \\
\hline Bovine IgG & 0.78 & ++ & 5.29 & $\mathbf{8 . 4 2}$ \\
\hline Rabbit IgG & 1.04 & +++ & 4.76 & 6.60 \\
\hline Chicken IgY & 0.16 & - & 3.50 & 5.73 \\
\hline Cat IgG & 1.35 & +++ & 3.79 & 6.01 \\
\hline Rat IgG & 0.38 & + & 4.86 & 6.52 \\
\hline
\end{tabular}

In this ELISA SpA and PLAG interact strongly with IgGs from cats, rabbits, mice, pigs, raccoons, coyotes, skunks, and dogs as shown in Table 16 . They react moderately with IgG from bovines, horse, donkeys, and mules.

SpG and PLAG sandwich ELISA: This ELISA is used to study the interactions between Streptococcal protein-G (SpG) and PLAG (PLAG) with different immunoglobulin preparations from mammalian and avian species. The 96 well microtitre plate is coated overnight at $4{ }^{\circ} \mathrm{C}$ with $2 \mu \mathrm{g} / \mu \mathrm{l}$ per well of $\mathrm{SpG}$ in carbonate-bicarbonate buffer $\mathrm{pH} 9.6$. Then plate is treated with bovine serum albumin solution and washed $4 \mathrm{X}$ with PBS-Tween. $50 \mu 1$ of immunoglobulins (1 $\mathrm{mg} / \mathrm{ml}$ ) is added and incubated for $1 \mathrm{~h}$ at room temperature and the microplate is rewashed $4 \mathrm{X}$ with PBS-Tween. Then $50 \mu$ l of peroxidase-labeled PLAG conjugate diluted 1:5000 in PBS-nonfat milk is added to each well and incubated for $1 \mathrm{~h}$ at RT. The plate is washed $4 \mathrm{X}$ with PBSTween. $50 \mu \mathrm{l}$ of $4 \mathrm{mg} / \mathrm{ml}$ o-phenylenediamine solution (OPD) is added and the plate is incubated 15 minutes at RT in the dark. The reaction is stopped with $50 \mu \mathrm{l}$ of $3 \mathrm{M} \mathrm{H} 2 \mathrm{SO} 4$ solution. The plate is visually assessed for the development of colour and read in a microplate reader at 492 $\mathrm{nm}$. A cut-off point is calculated as the mean of the optical density of negative controls times two. The cut-off point is 0.30 . 
Table 17. SpG and PLAG sandwich ELISA

\begin{tabular}{|l|c|c|c|c|}
\hline Immunoglobulins & XOD results & Binding affinity & $\begin{array}{l}\text { Coefficient of } \\
\text { variation (CV) } \\
\text { intra-assay (\%) }\end{array}$ & $\begin{array}{l}\text { CV inter-assay } \\
(\%)\end{array}$ \\
\hline Mule IgG & & & 3.25 & 4.79 \\
\hline Donkey IgG & $\mathbf{0 . 9 5}$ & +++ & 3.76 & 5.15 \\
\hline Horse IgG & 1.10 & +++ & 4.09 & 6.22 \\
\hline Dog IgG & 1.35 & +++ & 3.35 & 5.14 \\
\hline Skunk IgG & 1.30 & +++ & 3.78 & 5.53 \\
\hline Coyote IgG & 0.80 & +++ & 4.04 & 6.03 \\
\hline Raccoon IgG & 0.43 & ++ & 3.25 & 5.18 \\
\hline Ostrich IgY & $\mathbf{0 . 3 6}$ & + & 3.80 & 5.23 \\
\hline Pig IgG & 1.30 & ++5 & $\mathbf{3 . 9 5}$ & 4.35 \\
\hline Mouse IgG & 1.35 & +++ & 3.33 & 4.96 \\
\hline Bovine IgG & 1.05 & +++ & 3.56 & 5.35 \\
\hline Rabbit IgG & 1.13 & +++ & 3.07 & 5.67 \\
\hline Chicken IgY & 0.15 & - & 3.45 & 5.07 \\
\hline Cat IgG & 0.40 & + & 4.26 & 5.50 \\
\hline Rat IgG & 0.80 & ++ & 3.20 & \\
\hline
\end{tabular}

This immunoassay resembles the previous one, in this test SpG and PLAG interact strongly with IgG from species of rabbit, bovine, mouse, pig, skunk, dog, horse, donkey, and mule as shown in Table 17.

SpL and PLAG sandwich ELISA: This ELISA is used to study the interactions between Peptostreptococcal protein-L (SpL) and protein LAG (PLAG) with different immunoglobulin preparations from mammalian and avian species. The 96 well microtitre plate is coated overnight at $4^{\circ} \mathrm{C}$ with $2 \mu \mathrm{g} / \mu \mathrm{l}$ per well of $\mathrm{SpL}$ in carbonate-bicarbonate buffer $\mathrm{pH} 9.6$. Then plate is treated with bovine serum albumin solution and washed $4 \mathrm{X}$ with PBS-Tween. $50 \mu 1$ of immunoglobulins $(1 \mathrm{mg} / \mathrm{ml})$ is added and incubated for $1 \mathrm{~h}$ at room temperature and then, the microplate is rewashed $4 \mathrm{X}$ with PBS-Tween. Then $50 \mu \mathrm{l}$ of peroxidase-labeled PLAG conjugate diluted 1:5000 in PBS-non-fat milk is added to each well and incubated for $1 \mathrm{~h}$ at RT. The plate is washed $4 \mathrm{X}$ with PBS-Tween. $50 \mu \mathrm{l}$ of $4 \mathrm{mg} / \mathrm{ml}$ o-phenylenediamine solution (OPD) is added and the plate is incubated 15 minutes at RT in the dark. The reaction is stopped with $50 \mu \mathrm{l}$ of $3 \mathrm{M}$ $\mathrm{H} 2 \mathrm{SO} 4$ solution. The plate is visually assessed for the development of colour and read in a microplate reader at $492 \mathrm{~nm}$. A cut-off point is calculated as the mean of the optical density of negative controls times two. The cut-off point was 0.28 . 
Table 18. SpL and PLAG sandwich ELISA

\begin{tabular}{|l|c|c|c|c|}
\hline Immunoglobulins & XOD results & Binding affinity & $\begin{array}{l}\text { Coefficient of } \\
\text { variation (CV) } \\
\text { intra-assay (\%) }\end{array}$ & $\begin{array}{l}\text { CV inter-assay } \\
(\%)\end{array}$ \\
\hline Mule IgG & 0.17 & - & 3.85 & 5.50 \\
\hline Donkey IgG & 0.15 & - & 3.46 & 4.00 \\
\hline Horse IgG & 0.17 & - & 3.14 & 4.74 \\
\hline Dog IgG & 0.40 & + & 2.67 & 3.65 \\
\hline Skunk IgG & 0.14 & - & 3.01 & 5.54 \\
\hline Coyote IgG & 0.18 & - & 3.65 & 4.52 \\
\hline Raccoon IgG & 0.38 & + & 5.76 & 7.83 \\
\hline Ostrich IgY & 0.14 & - & 2.55 & 3.40 \\
\hline Pig IgG & 0.75 & +++ & 3.86 & 7.06 \\
\hline Mouse IgG & 0.90 & +++ & 2.89 & 4.98 \\
\hline Bovine IgG & 0.15 & - & 2.66 & 4.80 \\
\hline Rabbit IgG & 0.36 & + & 3.05 & 4.10 \\
\hline Chicken IgY & 0.14 & - & 3.10 & 6.35 \\
\hline Cat IgG & 0.14 & - & 4.14 & 7.95 \\
\hline Rat IgG & 0.12 & - & 3.70 & 5.18 \\
\hline
\end{tabular}

Table 18 shows the binding affinity of an ELISA, where the bacterial receptor SpL binds to only immunoglobulin $\mathrm{G}$ from fewer species of animals. It binds weakly to IgGs from rabbits, raccoons, and dogs and very strongly to IgGs of mice and pigs. SpL does not bind to the rest of the immunoglobulin panel. It supports the fact that in an ELISA the reagent bound to the solid phase is essential in immunodetection.

SpLA and PLAG sandwich ELISA: This ELISA is used to study the interactions between protein LA (SpLA) and protein-LAG (PLAG) with different immunoglobulin preparations from mammalian and avian species. The 96 well microtitre plate is coated overnight at $4{ }^{\circ} \mathrm{C}$ with 2 $\mu \mathrm{g} / \mu \mathrm{l}$ per well of SpLA in carbonate-bicarbonate buffer $\mathrm{pH}$ 9.6. Then plate is treated with bovine serum albumin solution and washed $4 \mathrm{X}$ with PBS-Tween. $50 \mu \mathrm{l}$ of immunoglobulins $(1 \mathrm{mg} / \mathrm{ml})$ is added and incubated for $1 \mathrm{~h}$ at room temperature and the microplate is rewashed $4 \mathrm{X}$ with PBSTween. Then $50 \mu$ l of peroxidase-labeled PLAG conjugate diluted 1:5000 in PBS-non-fat milk is added to each well and incubated for $1 \mathrm{~h}$ at RT. The plate is washed $4 \mathrm{X}$ with PBS-Tween. $50 \mu \mathrm{l}$ of $4 \mathrm{mg} / \mathrm{ml}$ o-phenylenediamine solution (OPD) is added and the plate is incubated 15 minutes at $\mathrm{RT}$ in the dark. The reaction is stopped with $50 \mu \mathrm{l}$ of $3 \mathrm{M} \mathrm{H} 2 \mathrm{SO} 4$ solution. The plate is visually assessed for the development of colour and read in a microplate reader at $492 \mathrm{~nm}$. A cut-off point is calculated as the mean of the optical density of negative controls times two. The cut-off point is 0.30 . 
Table 19. SpLA and PLAG sandwich ELISA

\begin{tabular}{|l|c|c|c|c|}
\hline Immunoglobulins & XOD results & Binding affinity & $\begin{array}{l}\text { Coefficient of } \\
\text { variation (CV) } \\
\text { intra-assay (\%) }\end{array}$ & $\begin{array}{l}\text { CV inter-assay } \\
(\%)\end{array}$ \\
\hline Mule IgG & 0.39 & + & 3.41 & 5.25 \\
\hline Donkey IgG & 0.44 & + & 3.22 & 4.61 \\
\hline Horse IgG & 0.48 & + & 3.45 & 5.09 \\
\hline Dog IgG & 0.75 & ++ & 4.27 & 5.80 \\
\hline Skunk IgG & 0.95 & +++ & 3.26 & 4.60 \\
\hline Coyote IgG & 0.68 & ++ & 3.89 & 5.18 \\
\hline Raccoon IgG & 1.10 & +++ & 4.03 & 5.79 \\
\hline Ostrich IgY & 0.33 & + & 3.68 & 5.79 \\
\hline Pig IgG & 1.35 & +++ & 4.00 & 5.24 \\
\hline Mouse IgG & 1.40 & +++ & 3.08 & 4.09 \\
\hline Bovine IgG & 0.78 & ++ & 3.85 & 5.43 \\
\hline Rabbit IgG & 1.05 & +++ & 4.09 & 5.12 \\
\hline Chicken IgY & 0.15 & - & 3.53 & 4.67 \\
\hline Cat IgG & 1.15 & +++ & 3.36 & 5.04 \\
\hline Rat IgG & 0.94 & +++ & 4.19 & 6.07 \\
\hline
\end{tabular}

Table 19 shows SpLA and PLAG binding strongly to the panel of Ig molecules. They react strongly with antibodies from species of skunk, raccoon, pig, rat, mouse, rabbit, and cat.

SpLG and PLAG sandwich ELISA: This ELISA is used to study the interactions between protein-LG (SpLG) and protein-LAG (PLAG) with different immunoglobulin preparations from mammalian and avian species. The 96 well microtitre plate is coated overnight at $4{ }^{\circ} \mathrm{C}$ with 2 $\mu \mathrm{g} / \mu \mathrm{l}$ per well of SpLG in carbonate-bicarbonate buffer $\mathrm{pH}$ 9.6. Then plate is treated with bovine serum albumin solution and washed $4 \mathrm{X}$ with PBS-Tween. $50 \mu \mathrm{l}$ of immunoglobulins $(1 \mathrm{mg} / \mathrm{ml})$ is added and incubated for $1 \mathrm{~h}$ at room temperature and the microplate is rewashed $4 \mathrm{X}$ with PBSTween. Then $50 \mu 1$ of peroxidase-labeled PLAG conjugate diluted 1:5000 in PBS-non-fat milk is added to each well and incubated for $1 \mathrm{~h}$ at RT. The plate is washed $4 \mathrm{X}$ with PBS-Tween. $50 \mu \mathrm{l}$ of $4 \mathrm{mg} / \mathrm{ml}$ o-phenylenediamine solution (OPD) is added and the plate is incubated 15 minutes at $\mathrm{RT}$ in the dark. The reaction is stopped with $50 \mu \mathrm{l}$ of $3 \mathrm{M} \mathrm{H} 2 \mathrm{SO} 4$ solution. The plate is visually assessed for the development of colour and read in a microplate reader at $492 \mathrm{~nm}$. A cut-off point is calculated as the mean of the optical density of negative controls times two. The cut-off point is 0.32 . 
Table 20. SpLG and PLAG sandwich ELISA

\begin{tabular}{|l|c|c|c|c|}
\hline Immunoglobulins & XOD results & Binding affinity & $\begin{array}{l}\text { Coefficient of } \\
\text { variation }(\mathbf{C V}) \\
\text { intra-assay }(\%)\end{array}$ & $\begin{array}{l}\text { CV inter-assay } \\
(\%)\end{array}$ \\
\hline Mule IgG & 0.79 & ++ & 4.13 & 6.88 \\
\hline Donkey IgG & 0.95 & +++ & 4.96 & 8.75 \\
\hline Horse IgG & 1.05 & +++ & 3.95 & 7.02 \\
\hline Dog IgG & 1.16 & +++ & 4.21 & 7.18 \\
\hline Skunk IgG & 0.97 & +++ & 4.50 & 8.11 \\
\hline Coyote IgG & 0.70 & ++ & 5.02 & 9.18 \\
\hline Raccoon IgG & 0.80 & ++ & 3.04 & 5.80 \\
\hline Ostrich IgY & 0.36 & + & 4.43 & 6.57 \\
\hline Pig IgG & 1.45 & +++ & 3.75 & 6.90 \\
\hline Mouse IgG & 1.30 & +++ & 5.23 & 9.67 \\
\hline Bovine IgG & 1.25 & +++ & 5.16 & 10.05 \\
\hline Rabbit IgG & 0.80 & +++ & 4.24 & 6.42 \\
\hline Chicken IgY & 0.16 & - & 3.98 & 5.43 \\
\hline Cat IgG & 0.17 & - & 4.14 & 7.28 \\
\hline Rat IgG & 1.45 & +++ & 4.60 & 8.25 \\
\hline
\end{tabular}

SpLG and PLAG react strongly with some Ig molecules from much species including horse, dog, rat, pig, and mouse as shown in Table 20. However, cat IgG does not react with one the bacterial proteins in this assay (SpLG).

SpAG and PLAG sandwich ELISA: This ELISA is used to study the interaction between protein-AG (SpAG) and protein-LAG (PLAG) with different immunoglobulin preparations from mammalian and avian species. The 96 well microtitre plate is coated overnight at $4{ }^{\circ} \mathrm{C}$ with 2 $\mu \mathrm{g} / \mu \mathrm{l}$ per well of SpAG in carbonate-bicarbonate buffer $\mathrm{pH} 9.6$. Then plate is treated with bovine serum albumin solution and washed $4 \mathrm{X}$ with PBS-Tween. $50 \mu 1$ of immunoglobulins (1 $\mathrm{mg} / \mathrm{ml}$ ) is added and incubated for $1 \mathrm{~h}$ at room temperature and the microplate is rewashed $4 \mathrm{X}$ with PBS-Tween. Then $50 \mu$ l of peroxidase-labeled PLAG conjugate diluted 1:5000 in PBS-nonfat milk is added to each well and incubated for $1 \mathrm{~h}$ at RT. The plate is washed $4 \mathrm{X}$ with PBSTween. $50 \mu 1$ of $4 \mathrm{mg} / \mathrm{ml}$ o-phenylenediamine solution (OPD) is added and the plate is incubated 15 minutes at RT in the dark. The reaction is stopped with $50 \mu 1$ of $3 \mathrm{M} \mathrm{H} 2 \mathrm{SO} 4$ solution. The plate is visually assessed for the development of colour and read in a microplate reader at 492 $\mathrm{nm}$. A cut-off point is calculated as the mean of the optical density of negative controls times two. The cut-off point is 0.28 . 
Table 21. SpAG and PLAG sandwich ELISA

\begin{tabular}{|l|c|c|c|c|}
\hline Immunoglobulins & XOD results & Binding affinity & $\begin{array}{l}\text { Coefficient of } \\
\text { variation (CV) } \\
\text { intra-assay (\%) }\end{array}$ & $\begin{array}{l}\text { CV inter-assay } \\
(\%)\end{array}$ \\
\hline Mule IgG & 0.92 & +++ & 3.15 & 4.07 \\
\hline Donkey IgG & 0.98 & +++ & 3.67 & 4.18 \\
\hline Horse IgG & 0.90 & +++ & 4.15 & 5.15 \\
\hline Dog IgG & 1.35 & +++ & 3.22 & 4.34 \\
\hline Skunk IgG & 1.44 & +++ & 3.06 & 4.67 \\
\hline Coyote IgG & 0.80 & ++ & 3.45 & 5.05 \\
\hline Raccoon IgG & 0.93 & +++ & 4.08 & 5.91 \\
\hline Ostrich IgY & 0.33 & + & 4.32 & 5.94 \\
\hline Pig IgG & 1.35 & +++ & 3.56 & 5.75 \\
\hline Mouse IgG & 1.25 & +++ & 4.05 & 6.10 \\
\hline Bovine IgG & 0.95 & +++ & 3.06 & 4.78 \\
\hline Rabbit IgG & 1.08 & +++ & 3.37 & 5.04 \\
\hline Chicken IgY & 0.14 & - & 3.40 & 5.08 \\
\hline Cat IgG & 1.09 & +++ & 3.74 & 4.94 \\
\hline Rat IgG & 0.62 & ++ & 3.31 & 4.08 \\
\hline
\end{tabular}

Table 21 depicts that all immunoglobulins react effectively with SpAG-PLAG, except the ostrich IgY that binds weakly and the chicken $\operatorname{IgY}$ that does not react with any of the bacterial proteins and it is used as a negative control in this panel of 35 ELISAs.

PLAG and PLAG sandwich ELISA: This ELISA is used to study the interactions of proteinLAG (PLAG) with different immunoglobulin preparations from mammalian and avian species. The 96 well microtitre plate is coated overnight at $4^{\circ} \mathrm{C}$ with $2 \mu \mathrm{g} / \mu \mathrm{l}$ per well of PLAG in carbonate-bicarbonate buffer $\mathrm{pH}$ 9.6. Then plate is treated with bovine serum albumin solution and washed $4 \mathrm{X}$ with PBS-Tween. $50 \mu \mathrm{l}$ of immunoglobulins $(1 \mathrm{mg} / \mathrm{ml})$ is added and incubated for $1 \mathrm{~h}$ at room temperature and the microplate is rewashed $4 \mathrm{X}$ with PBS-Tween. Then $50 \mu \mathrm{l}$ of peroxidase-labeled PLAG conjugate diluted 1:5000 in PBS-non-fat milk is added to each well and incubated for $1 \mathrm{~h}$ at RT. The plate is washed $4 \mathrm{X}$ with PBS-Tween. $50 \mu \mathrm{lof} 4 \mathrm{mg} / \mathrm{ml} \mathrm{o-}$ phenylenediamine solution (OPD) is added and the plate is incubated 15 minutes at RT in the dark. The reaction is stopped with $50 \mu \mathrm{l}$ of $3 \mathrm{M} \mathrm{H} 2 \mathrm{SO} 4$ solution. The plate is visually assessed for the development of colour and read in a microplate reader at $492 \mathrm{~nm}$. A cut-off point is calculated as the mean of the optical density of negative controls times two. The cut-off point is 0.32 . 
Table 22. PLAG and PLAG sandwich ELISA

\begin{tabular}{|l|c|c|c|c|}
\hline Immunoglobulins & XOD results & Binding affinity & $\begin{array}{l}\text { Coefficient of } \\
\text { variation }(\mathbf{C V}) \\
\text { intra-assay }(\%)\end{array}$ & $\begin{array}{l}\text { CV inter-assay } \\
(\%)\end{array}$ \\
\hline Mule IgG & 1.05 & +++ & 3.59 & 5.78 \\
\hline Donkey IgG & 0.98 & +++ & 4.15 & 5.08 \\
\hline Horse IgG & 1.14 & +++ & 3.62 & 5.27 \\
\hline Dog IgG & 1.45 & +++ & 4.15 & 6.20 \\
\hline Skunk IgG & 1.38 & +++ & 4.06 & 5.67 \\
\hline Coyote IgG & 0.97 & +++ & 3.79 & 4.88 \\
\hline Raccoon IgG & 1.35 & +++ & 3.28 & 5.07 \\
\hline Ostrich IgY & $\mathbf{0 . 5 0}$ & + & 3.20 & 5.08 \\
\hline Pig IgG & 1.51 & +++ & 3.75 & 5.36 \\
\hline Mouse IgG & 1.33 & +++ & 3.62 & 5.21 \\
\hline Bovine IgG & 1.12 & +++ & 3.30 & 5.07 \\
\hline Rabbit IgG & 1.30 & +++ & 4.33 & 6.08 \\
\hline Chicken IgY & 0.16 & - & 3.54 & 5.59 \\
\hline Cat IgG & 1.02 & +++ & 3.95 & 5.14 \\
\hline Rat IgG & 0.97 & +++ & 4.90 & 6.74 \\
\hline
\end{tabular}

This is a very effective immunoassay. Fourteen out of 15 different immunoglobulins react with PLAG as shown in Table 22. A system like this brings the possibility or danger of causing steric hindrance. Nevertheless, it did not happen, and the fact that $86.6 \%$ of the immunoglobulins bound strongly to this hybrid protein proves it.

PLAG and SpL sandwich ELISA: This ELISA is used to study the interactions between protein-LAG (PLAG) and Peptostreptococcal protein-L (SpL) with different immunoglobulin preparations from mammalian and avian species. The 96 well microtitre plate is coated overnight at $4^{\circ} \mathrm{C}$ with $2 \mu \mathrm{g} / \mu \mathrm{l}$ per well of PLAG in carbonate-bicarbonate buffer $\mathrm{pH} 9.6$. Then plate is treated with bovine serum albumin solution and washed $4 \mathrm{X}$ with PBS-Tween. $50 \mu 1$ of immunoglobulins $(1 \mathrm{mg} / \mathrm{ml})$ is added and incubated for $1 \mathrm{~h}$ at room temperature and then, the microplate is rewashed $4 \mathrm{X}$ with PBS-Tween. Then $50 \mu \mathrm{l}$ of peroxidase-labeled SpL conjugate diluted 1:5000 in PBS-non-fat milk is added to each well and incubated for $1 \mathrm{~h}$ at RT. The plate is washed $4 \mathrm{X}$ with PBS-Tween. $50 \mu \mathrm{l}$ of $4 \mathrm{mg} / \mathrm{ml}$ o-phenylenediamine solution (OPD) is added and the plate is incubated 15 minutes at RT in the dark. The reaction is stopped with $50 \mu 1$ of $3 \mathrm{M}$ $\mathrm{H} 2 \mathrm{SO} 4$ solution. The plate is visually assessed for the development of colour and read in a microplate reader at $492 \mathrm{~nm}$. A cut-off point is calculated as the mean of the optical density of negative controls times two. The cut-off point is 0.28 . 
Table 23. PLAG and SpL sandwich ELISA

\begin{tabular}{|l|c|c|c|c|}
\hline Immunoglobulins & XOD results & Binding affinity & $\begin{array}{l}\text { Coefficient of } \\
\text { variation (CV) } \\
\text { intra-assay (\%) }\end{array}$ & $\begin{array}{l}\text { CV inter-assay } \\
(\%)\end{array}$ \\
\hline Mule IgG & 0.23 & - & 3.85 & 5.50 \\
\hline Donkey IgG & 0.15 & - & 3.46 & 4.02 \\
\hline Horse IgG & 0.17 & - & 3.14 & 4.74 \\
\hline Dog IgG & 0.40 & + & 2.67 & 3.65 \\
\hline Skunk IgG & 0.14 & - & 3.01 & 5.54 \\
\hline Coyote IgG & 0.18 & - & 3.65 & 4.54 \\
\hline Raccoon IgG & 0.38 & + & 2.76 & 4.83 \\
\hline Ostrich IgY & 0.14 & - & 3.35 & 6.40 \\
\hline Pig IgG & 0.75 & +++ & 2.86 & 4.82 \\
\hline Mouse IgG & 0.90 & +++ & 2.80 & 3.77 \\
\hline Bovine IgG & 0.20 & - & 2.88 & 3.50 \\
\hline Rabbit IgG & 0.39 & + & 3.05 & 5.10 \\
\hline Chicken IgY & 0.14 & - & 2.95 & 3.89 \\
\hline Cat IgG & 0.12 & - & 3.08 & 5.70 \\
\hline Rat IgG & 0.12 & - & 2.88 & 4.60 \\
\hline
\end{tabular}

Table 23 shows the PLAG-SpL sandwich ELISA is an interesting assay, because it is expected that since PLAG is involved, more higher affinities can be picked up. Unfortunately, this assay's sensitivity is low because it uses a peroxidase conjugated $\mathrm{SpL}$ that fails to interact with many immunoglobulins.

PLAG and SpA sandwich ELISA: This ELISA is used to study the interactions between protein-LAG (PLAG) and Staphylococcal protein-A (SpA) with different immunoglobulin preparations from mammalian and avian species. The 96 well microtitre plate is coated overnight at $4^{\circ} \mathrm{C}$ with $2 \mu \mathrm{g} / \mu \mathrm{l}$ per well of PLAG in carbonate-bicarbonate buffer $\mathrm{pH} 9.6$. Then plate is treated with bovine serum albumin solution and washed $4 \mathrm{X}$ with PBS-Tween. $50 \mu 1$ of immunoglobulins $(1 \mathrm{mg} / \mathrm{ml})$ is added and incubated for $1 \mathrm{~h}$ at room temperature and the microplate is rewashed $4 \mathrm{X}$ with PBS-Tween. Then $50 \mu 1$ of peroxidase-labeled SpA conjugate diluted 1:5000 in PBS-non-fat milk is added to each well and incubated for $1 \mathrm{~h}$ at RT. The plate is washed $4 \mathrm{X}$ with PBS-Tween. $50 \mu 1$ of $4 \mathrm{mg} / \mathrm{ml}$ o-phenylenediamine solution (OPD) is added and the plate is incubated 15 minutes at RT in the dark. The reaction is stopped with $50 \mu 1$ of $3 \mathrm{M}$ $\mathrm{H} 2 \mathrm{SO} 4$ solution. The plate is visually assessed for the development of colour and read in a microplate reader at $492 \mathrm{~nm}$. A cut-off point is calculated as the mean of the optical density of negative controls times two. The cut-off point is 0.30 . 
Table 24. PLAG and SpA sandwich ELISA

\begin{tabular}{|l|c|c|c|c|}
\hline Immunoglobulins & XOD results & Binding affinity & $\begin{array}{l}\text { Coefficient of } \\
\text { variation (CV) } \\
\text { intra-assay (\%) }\end{array}$ & $\begin{array}{l}\text { CV inter-assay } \\
(\%)\end{array}$ \\
\hline Mule IgG & 0.65 & ++ & 4.22 & 8.15 \\
\hline Donkey IgG & 0.70 & ++ & 4.57 & 7.90 \\
\hline Horse IgG & 0.74 & ++ & 4.05 & 6.70 \\
\hline Dog IgG & 1.20 & +++ & 3.67 & 6.86 \\
\hline Skunk IgG & 1.27 & +++ & 4.44 & 8.19 \\
\hline Coyote IgG & 0.80 & ++ & 3.56 & 5.80 \\
\hline Raccoon IgG & 1.25 & +++ & 5.01 & 9.33 \\
\hline Ostrich IgY & 0.45 & + & 3.79 & 7.10 \\
\hline Pig IgG & 1.30 & +++ & 4.57 & 7.97 \\
\hline Mouse IgG & 1.42 & +++ & 3.06 & 5.75 \\
\hline Bovine IgG & 0.45 & + & 4.90 & 8.74 \\
\hline Rabbit IgG & 1.13 & +++ & 3.76 & 6.03 \\
\hline Chicken IgY & 0.15 & - & 3.55 & 5.91 \\
\hline Cat IgG & 1.17 & +++ & 3.69 & 6.54 \\
\hline Rat IgG & 0.35 & + & 4.68 & 7.05 \\
\hline
\end{tabular}

Table 24 shows an ELISA where SpA interacts strongly with the $46.6 \%$ of the panel of immunoglobulins (7 out of 15). SpA binds moderately to IgG of species of mule, donkey, coyote, and horse.

PLAG and SpG sandwich ELISA: This ELISA is used to study the interactions between protein-LAG (PLAG) and Streptococcal protein-G $(\mathrm{SpG})$ with different immunoglobulin preparations from mammalian and avian species. The 96 well microtitre plate is coated overnight at $4^{\circ} \mathrm{C}$ with $2 \mu \mathrm{g} / \mu 1$ per well of PLAG in carbonate-bicarbonate buffer $\mathrm{pH} 9.6$. Then plate is treated with bovine serum albumin solution and washed $4 \mathrm{X}$ with PBS-Tween. $50 \mu \mathrm{l}$ of immunoglobulins $(1 \mathrm{mg} / \mathrm{ml})$ is added and incubated for $1 \mathrm{~h}$ at room temperature and the microplate is rewashed $4 \mathrm{X}$ with PBS-Tween. Then $50 \mu 1$ of peroxidase-labeled SpG conjugate diluted 1:5000 in PBS-non-fat milk is added to each well and incubated for $1 \mathrm{~h}$ at RT. The plate is washed $4 \mathrm{X}$ with PBS-Tween. $50 \mu 1$ of $4 \mathrm{mg} / \mathrm{ml}$ o-phenylenediamine solution (OPD) is added and the plate is incubated 15 minutes at RT in the dark. The reaction is stopped with $50 \mu 1$ of $3 \mathrm{M}$ $\mathrm{H} 2 \mathrm{SO} 4$ solution. The plate is visually assessed for the development of colour and read in a microplate reader at $492 \mathrm{~nm}$. A cut-off point is calculated as the mean of the optical density of negative controls times two. The cut-off point is 0.30 . 
Table 25. PLAG and SpG sandwich ELISA

\begin{tabular}{|l|c|c|c|c|}
\hline Immunoglobulins & XOD results & Binding affinity & $\begin{array}{l}\text { Coefficient of } \\
\text { variation }(\mathbf{C V}) \\
\text { intra-assay }(\%)\end{array}$ & $\begin{array}{l}\text { CV inter-assay } \\
(\%)\end{array}$ \\
\hline Mule IgG & 1.03 & +++ & 2.83 & 5.22 \\
\hline Donkey IgG & 1.10 & +++ & 2.95 & 4.89 \\
\hline Horse IgG & 1.15 & +++ & 2.86 & 5.65 \\
\hline Dog IgG & 1.50 & +++ & 3.05 & 6.38 \\
\hline Skunk IgG & 1.44 & +++ & 3.67 & 6.15 \\
\hline Coyote IgG & 0.75 & ++ & 4.80 & 6.76 \\
\hline Raccoon IgG & 0.40 & + & 2.89 & 5.73 \\
\hline Ostrich IgY & 0.36 & + & 3.49 & 6.05 \\
\hline Pig IgG & 1.53 & +++ & 3.37 & 5.88 \\
\hline Mouse IgG & 1.48 & +++ & 2.81 & 4.80 \\
\hline Bovine IgG & 0.99 & +++ & 3.41 & 5.75 \\
\hline Rabbit IgG & 1.02 & +++ & 4.05 & 7.07 \\
\hline Chicken IgY & 0.15 & - & 2.81 & 4.73 \\
\hline Cat IgG & 0.15 & - & 3.08 & 5.14 \\
\hline Rat IgG & 1.28 & +++ & 3.90 & 6.01 \\
\hline
\end{tabular}

Table 25 shows a very powerful assay where SpG interact strongly with $66.6 \%$ of the immunoglobulin panel (10 out of 15 ). SpG does not react with chicken IgY and cat IgG.

PLAG and SpLG sandwich ELISA: This ELISA is used to study the interactions between protein-LAG (PLAG) and protein-LG (SpLG) with different immunoglobulin preparations from mammalian species. The 96 well microtitre plate is coated overnight at $4^{\circ} \mathrm{C}$ with $2 \mu \mathrm{g} / \mu \mathrm{l}$ per well of PLAG in carbonate-bicarbonate buffer $\mathrm{pH}$ 9.6. Then plate is treated with bovine serum albumin solution and washed $4 \mathrm{X}$ with PBS-Tween. $50 \mu \mathrm{l}$ of immunoglobulins $(1 \mathrm{mg} / \mathrm{ml})$ is added and incubated for $1 \mathrm{~h}$ at room temperature and the microplate is rewashed $4 \mathrm{X}$ with PBSTween. Then $50 \mu 1$ of peroxidase-labeled SpLG conjugate diluted 1:5000 in PBS-non-fat milk is added to each well and incubated for $1 \mathrm{~h}$ at RT. The plate is washed $4 \mathrm{X}$ with PBS-Tween. $50 \mu \mathrm{l}$ of $4 \mathrm{mg} / \mathrm{ml}$ o-phenylenediamine solution (OPD) is added and the plate is incubated 15 minutes at $\mathrm{RT}$ in the dark. The reaction is stopped with $50 \mu \mathrm{l}$ of $3 \mathrm{M} \mathrm{H} 2 \mathrm{SO} 4$ solution. The plate is visually assessed for the development of colour and read in a microplate reader at $492 \mathrm{~nm}$. A cut-off point is calculated as the mean of the optical density of negative controls times two. The cut-off point is 0.34 . 
Table 26. PLAG and SpLG sandwich ELISA

\begin{tabular}{|l|c|c|c|c|}
\hline Immunoglobulins & XOD results & Binding affinity & $\begin{array}{l}\text { Coefficient of } \\
\text { variation (CV) } \\
\text { intra-assay }(\%)\end{array}$ & $\begin{array}{l}\text { CV inter-assay } \\
(\%)\end{array}$ \\
\hline Mule IgG & 1.10 & +++ & 3.55 & 7.04 \\
\hline Donkey IgG & 1.22 & +++ & 3.65 & 6.19 \\
\hline Horse IgG & 1.28 & +++ & 4.24 & 6.86 \\
\hline Dog IgG & 1.30 & +++ & 3.15 & 5.75 \\
\hline Skunk IgG & 1.35 & +++ & 4.28 & 6.30 \\
\hline Coyote IgG & $\mathbf{0 . 4 8}$ & + & 3.70 & 6.05 \\
\hline Raccoon IgG & $\mathbf{0 . 7 0}$ & ++ & 4.08 & $\mathbf{3 . 4 5}$ \\
\hline Ostrich IgY & $\mathbf{0 . 2 0}$ & - & 3.66 & 6.71 \\
\hline Pig IgG & 1.35 & +++ & 3.58 & 5.99 \\
\hline Mouse IgG & 1.45 & +++ & 3.69 & 6.43 \\
\hline Bovine IgG & 1.08 & +++ & 3.54 & 5.07 \\
\hline Rabbit IgG & 1.14 & +++ & 3.78 & 6.09 \\
\hline Chicken IgY & 0.17 & - & 3.34 & 5.70 \\
\hline Cat IgG & 0.11 & - & 3.46 & 6.28 \\
\hline Rat IgG & 1.25 & +++ & 3.57 & 7.07 \\
\hline
\end{tabular}

Table 26 depicts the PLAG and SpLG sandwich ELISA. It is an interesting assay because in its solid phase it binds to 14 out of 15 immunoglobulins. On the other hand, the conjugate (SpLGHRP) does not interact with the two avian immunoglobulins, neither the cat $\mathrm{IgG}$, nor very weakly react with the coyote IgG. However, this system interacts strongly with IgG from species of horse, pig, rat, among other species.

PLAG and SpLA sandwich ELISA: This ELISA is used to study the interactions between protein-LAG (PLAG) and protein-LA (SpLA) with different immunoglobulin preparations from mammalian and avian species. The 96 well microtitre plate is coated overnight at $4{ }^{\circ} \mathrm{C}$ with 2 $\mu \mathrm{g} / \mu \mathrm{l}$ per well of PLAG in carbonate-bicarbonate buffer $\mathrm{pH} 9.6$. Then plate is treated with bovine serum albumin solution and washed $4 \mathrm{X}$ with PBS-Tween. $50 \mu 1$ of immunoglobulins (1 $\mathrm{mg} / \mathrm{ml}$ ) is added and incubated for $1 \mathrm{~h}$ at room temperature and the microplate is rewashed $4 \mathrm{X}$ with PBS-Tween. Then $50 \mu$ l of peroxidase-labeled SpLA conjugate diluted 1:5000 in PBS-nonfat milk is added to each well and incubated for $1 \mathrm{~h}$ at RT. The plate is washed $4 \mathrm{X}$ with PBSTween. $50 \mu 1$ of $4 \mathrm{mg} / \mathrm{ml}$ o-phenylenediamine solution (OPD) is added and the plate is incubated 15 minutes at RT in the dark. The reaction is stopped with $50 \mu 1$ of $3 \mathrm{M} \mathrm{H} 2 \mathrm{SO} 4$ solution. The plate is visually assessed for the development of colour and read in a microplate reader at 492 $\mathrm{nm}$. A cut-off point is calculated as the mean of the optical density of negative controls times two. The cut-off point is 0.32 . 
Table 27. PLAG and SpLA sandwich ELISA

\begin{tabular}{|l|c|c|c|c|}
\hline Immunoglobulins & XOD results & Binding affinity & $\begin{array}{l}\text { Coefficient of } \\
\text { variation }(\mathbf{C V}) \\
\text { intra-assay }(\%)\end{array}$ & $\begin{array}{l}\text { CV inter-assay } \\
(\%)\end{array}$ \\
\hline Mule IgG & 0.68 & ++ & 3.55 & 6.72 \\
\hline Donkey IgG & 0.75 & ++ & 4.88 & 7.77 \\
\hline Horse IgG & 0.75 & ++ & 3.85 & 5.06 \\
\hline Dog IgG & 1.15 & +++ & 4.08 & 8.19 \\
\hline Skunk IgG & 1.00 & +++ & 3.45 & 6.13 \\
\hline Coyote IgG & 0.80 & ++ & 4.60 & 7.36 \\
\hline Raccoon IgG & 1.15 & +++ & 3.85 & 5.09 \\
\hline Ostrich IgY & 0.42 & + & 3.75 & 5.50 \\
\hline Pig IgG & 1.26 & +++ & 4.65 & 6.22 \\
\hline Mouse IgG & 1.31 & +++ & 2.96 & 5.18 \\
\hline Bovine IgG & 0.80 & ++ & 3.19 & 5.58 \\
\hline Rabbit IgG & 0.98 & +++ & 4.34 & 7.20 \\
\hline Chicken IgY & 0.16 & - & 3.08 & 5.35 \\
\hline Cat IgG & 1.25 & +++ & 5.24 & $\mathbf{8 . 6 4}$ \\
\hline Rat IgG & 0.35 & + & 4.50 & 7.13 \\
\hline
\end{tabular}

Table 27 shows the binding affinity of SpLA and PLAG to the immunoglobulin panel. They interact effectively with IgGs of cats, rabbits, mice, pigs, raccoons, skunks, and dogs.

Table 28. PLAG and SpAG sandwich ELISA: This ELISA is used to study the interactions between protein-LAG (PLAG) and protein-AG (SpAG) with different immunoglobulin preparations from mammalian and avian species. The 96 well microtitre plate is coated overnight at $4{ }^{\circ} \mathrm{C}$ with $2 \mu \mathrm{g} / \mu \mathrm{l}$ per well of PLAG in carbonate-bicarbonate buffer $\mathrm{pH} 9.6$. Then plate is treated with bovine serum albumin solution and washed $4 \mathrm{X}$ with PBS-Tween. $50 \mu 1$ of immunoglobulins $(1 \mathrm{mg} / \mathrm{ml})$ is added and incubated for $1 \mathrm{~h}$ at room temperature and the microplate is rewashed $4 \mathrm{X}$ with PBS-Tween. Then $50 \mu \mathrm{l}$ of peroxidase-labeled SpAG conjugate diluted 1:5000 in PBS-non-fat milk is added to each well and incubated for $1 \mathrm{~h}$ at RT. The plate is washed $4 \mathrm{X}$ with PBS-Tween. $50 \mu \mathrm{l}$ of $4 \mathrm{mg} / \mathrm{ml}$ o-phenylenediamine solution (OPD) is added and the plate is incubated 15 minutes at RT in the dark. The reaction is stopped with $50 \mu 1$ of $3 \mathrm{M}$ $\mathrm{H} 2 \mathrm{SO} 4$ solution. The plate is visually assessed for the development of colour and read in a microplate reader at $492 \mathrm{~nm}$. A cut-off point is calculated as the mean of the optical density of negative controls times two. The cut-off point is 0.36 . 
Table 28. PLAG and SpAG sandwich ELISA

\begin{tabular}{|l|c|c|c|c|}
\hline Immunoglobulins & XOD results & Binding affinity & $\begin{array}{l}\text { Coefficient of } \\
\text { variation }(\mathbf{C V}) \\
\text { intra-assay }(\%)\end{array}$ & $\begin{array}{l}\text { CV inter-assay } \\
(\%)\end{array}$ \\
\hline Mule IgG & 1.25 & +++ & 3.67 & 6.63 \\
\hline Donkey IgG & 1.28 & +++ & 2.53 & 5.29 \\
\hline Horse IgG & 1.35 & +++ & 4.45 & 8.15 \\
\hline Dog IgG & 1.50 & +++ & 3.20 & 5.02 \\
\hline Skunk IgG & 1.44 & +++ & 3.09 & 5.79 \\
\hline Coyote IgG & 1.11 & +++ & 4.88 & 7.66 \\
\hline Raccoon IgG & 0.80 & ++ & 3.28 & 5.55 \\
\hline Ostrich IgY & 0.37 & + & 3.13 & 6.09 \\
\hline Pig IgG & 1.55 & +++ & 5.24 & 8.46 \\
\hline Mouse IgG & 1.60 & +++ & 3.29 & 4.97 \\
\hline Bovine IgG & 1.07 & +++ & 3.18 & 5.06 \\
\hline Rabbit IgG & 1.16 & +++ & 3.77 & 6.01 \\
\hline Chicken IgY & 0.18 & - & 2.85 & 4.79 \\
\hline Cat IgG & 0.95 & +++ & 4.45 & 7.13 \\
\hline Rat IgG & 1.05 & +++ & 3.43 & 7.05 \\
\hline
\end{tabular}

Table 28 represents an effective immunoassay capable of strongly interacting with IgGs of many species. Twelve out of 15 immunoglobulins (80\%) bind strongly to SpAG.

SpA Direct ELISA: This ELISA is used to study the interactions of Staphylococcal protein-A (SpA) with diverse immunoglobulins. The 96 well microtitre plate is coated overnight at $4^{\circ} \mathrm{C}$ with $1 \mu \mathrm{g} / \mu \mathrm{l}$ per well of purified immunoglobulins in carbonate-bicarbonate buffer $\mathrm{pH}$ 9.6. Then, plate is treated with bovine serum albumin solution and washed $4 \mathrm{X}$ with PBS-Tween. Then, 50 $\mu 1$ of peroxidase-labeled-protein-A conjugate diluted 1:3000 in PBS-non-fat milk is added to each well and incubated for $1.30 \mathrm{~h}$ at RT. After that, the plate is washed $4 \mathrm{X}$ with PBS-Tween. Pipette $50 \mu \mathrm{l}$ of 3,3',5,5' - tetramethylbenzidine (TMB; Sigma-Aldrich) to each well. The reaction is stopped with $50 \mu 1$ of $3 \mathrm{M} \mathrm{H} 2 \mathrm{SO} 4$ solution. The plate is visually assessed for the development of colour and read in a microplate reader at $450 \mathrm{~nm}$. A cut-off point is calculated as the mean of the optical density of negative controls times two. The cut-off point was 0.28 . 
Table 29. SpA Direct ELISA

\begin{tabular}{|l|c|c|c|c|}
\hline Immunoglobulins & XOD results & Binding affinity & $\begin{array}{l}\text { Coefficient of } \\
\text { variation (CV) } \\
\text { intra-assay (\%) }\end{array}$ & $\begin{array}{l}\text { CV inter-assay } \\
(\%)\end{array}$ \\
\hline Mule IgG & 0.37 & + & 3.03 & 5.20 \\
\hline Donkey IgG & 0.43 & + & 3.75 & 7.35 \\
\hline Horse IgG & 0.52 & ++ & 4.32 & 6.08 \\
\hline Dog IgG & 0.95 & +++ & 3.22 & 5.07 \\
\hline Skunk IgG & 0.90 & +++ & 5.05 & 8.37 \\
\hline Coyote IgG & 0.61 & ++ & 3.89 & 6.04 \\
\hline Raccoon IgG & 0.96 & +++ & 4.48 & 7.12 \\
\hline Ostrich IgY & 0.35 & + & 3.75 & 6.18 \\
\hline Pig IgG & 0.95 & +++ & 3.87 & 5.75 \\
\hline Mouse IgG & 0.98 & +++ & 2.95 & 4.18 \\
\hline Bovine IgG & 0.60 & ++ & 3.26 & 5.05 \\
\hline Rabbit IgG & 0.90 & +++ & 3.74 & 6.35 \\
\hline Chicken IgY & 0.14 & - & 2.58 & 5.19 \\
\hline Cat IgG & 1.05 & +++ & 5.16 & 9.13 \\
\hline Rat IgG & 0.39 & + & 3.80 & 6.15 \\
\hline
\end{tabular}

Table 29 shows SpA that binds strongly to the $46.66 \%$ of the panel of immunoglobulins. However, it binds moderately to IgGs of horses, coyotes, and bovines.

SpG Direct ELISA: This ELISA is used to study the interactions of Streptococcal protein-G (SpG) with diverse immunoglobulins. The 96 well microtitre plate is coated overnight at $4^{\circ} \mathrm{C}$ with $1 \mu \mathrm{g} / \mu \mathrm{l}$ per well of purified immunoglobulins in carbonate-bicarbonate buffer $\mathrm{pH}$ 9.6. Then, plate is treated with bovine serum albumin solution and washed $4 \mathrm{X}$ with PBS-Tween. Then, 50 $\mu 1$ of peroxidase-labeled-protein-G conjugate diluted 1:3000 in PBS-non-fat milk is added to each well and incubated for $1.30 \mathrm{~h}$ at RT. After that, the plate is washed $4 \mathrm{X}$ with PBS-Tween. Pipette $50 \mu$ of 3,3',5,5' - tetramethylbenzidine (TMB; Sigma-Aldrich) to each well. The reaction is stopped with $50 \mu \mathrm{l}$ of $3 \mathrm{M} \mathrm{H} 2 \mathrm{SO} 4$ solution. The plate is visually assessed for the development of colour and read in a microplate reader at $450 \mathrm{~nm}$. A cut-off point is calculated as the mean of the optical density of negative controls times two. The cut-off point is 0.28 . 
Table 30. SpG Direct ELISA

\begin{tabular}{|l|c|c|c|c|}
\hline Immunoglobulins & XOD results & Binding affinity & $\begin{array}{l}\text { Coefficient of } \\
\text { variation (CV) } \\
\text { intra-assay (\%) }\end{array}$ & $\begin{array}{l}\text { CV inter-assay } \\
(\%)\end{array}$ \\
\hline Mule IgG & 0.70 & ++ & 3.86 & 6.13 \\
\hline Donkey IgG & 0.75 & ++ & 3.50 & 5.84 \\
\hline Horse IgG & 0.87 & +++ & 4.12 & 7.06 \\
\hline Dog IgG & 0.95 & +++ & 3.59 & 6.61 \\
\hline Skunk IgG & 0.90 & +++ & 4.03 & 7.35 \\
\hline Coyote IgG & 0.35 & + & 4.29 & 8.08 \\
\hline Raccoon IgG & 0.33 & + & 3.67 & 5.06 \\
\hline Ostrich IgY & 0.07 & - & 5.25 & 8.66 \\
\hline Pig IgG & 1.11 & +++ & 3.44 & 6.15 \\
\hline Mouse IgG & 1.05 & +++ & 4.04 & 6.57 \\
\hline Bovine IgG & 0.95 & +++ & 3.94 & 7.32 \\
\hline Rabbit IgG & 0.88 & +++ & 4.68 & $\mathbf{8 . 0 2}$ \\
\hline Chicken IgY & 0.07 & - & 2.95 & 4.74 \\
\hline Cat IgG & 0.14 & - & 3.52 & 5.08 \\
\hline Rat IgG & 0.96 & +++ & 3.67 & 5.86 \\
\hline
\end{tabular}

Table 30 shows a direct ELISA where SpG binds strongly to $53.33 \%$ of the immunoglobulin panel (8 out of 15 Igs).

SpL Direct ELISA: This ELISA is used to study the interactions of Peptostreptococcal protein$\mathrm{L}(\mathrm{SpL})$ with diverse immunoglobulins. The 96 well microtitre plate is coated overnight at $4^{\circ} \mathrm{C}$ with $1 \mu \mathrm{g} / \mu \mathrm{l}$ per well of purified immunoglobulins in carbonate-bicarbonate buffer $\mathrm{pH} 9.6$. Then, plate is treated with bovine serum albumin solution and washed $4 \mathrm{X}$ with PBS-Tween. Then, 50 $\mu 1$ of peroxidase-labeled-protein-L conjugate diluted 1:3000 in PBS-non-fat milk is added to each well and incubated for 1.30h at RT. After that, the plate is washed $4 \mathrm{X}$ with PBS-Tween. Pipette $50 \mu \mathrm{l}$ of 3,3',5,5' - tetramethylbenzidine (TMB; Sigma-Aldrich) to each well. The reaction is stopped with $50 \mu \mathrm{l}$ of $3 \mathrm{M} \mathrm{H} 2 \mathrm{SO} 4$ solution. The plate is visually assessed for the development of colour and read in a microplate reader at $450 \mathrm{~nm}$. A cut-off point is calculated as the mean of the optical density of negative controls times two. The cut-off point is 0.24 . 
Table 31. SpL Direct ELISA

\begin{tabular}{|l|c|c|c|c|}
\hline Immunoglobulins & XOD results & Binding affinity & $\begin{array}{l}\text { Coefficient of } \\
\text { variation (CV) } \\
\text { intra-assay (\%) }\end{array}$ & $\begin{array}{l}\text { CV inter-assay } \\
(\%)\end{array}$ \\
\hline Mule IgG & & - & 2.84 & 4.41 \\
\hline Donkey IgG & 0.09 & - & 2.50 & 4.15 \\
\hline Horse IgG & 0.15 & - & 2.78 & 3.85 \\
\hline Dog IgG & 0.33 & + & 2.36 & 3.60 \\
\hline Skunk IgG & 0.14 & - & 3.01 & 5.73 \\
\hline Coyote IgG & 0.14 & - & 2.80 & 4.08 \\
\hline Raccoon IgG & 0.43 & + & 3.99 & 6.06 \\
\hline Ostrich IgY & 0.09 & - & 2.54 & 3.07 \\
\hline Pig IgG & 0.90 & +++ & 3.80 & 7.43 \\
\hline Mouse IgG & 0.98 & +++ & 5.47 & 8.98 \\
\hline Bovine IgG & 0.08 & - & 3.58 & 5.20 \\
\hline Rabbit IgG & 0.34 & + & 4.67 & 7.23 \\
\hline Chicken IgY & 0.06 & - & 2.40 & 4.65 \\
\hline Cat IgG & 0.12 & - & 4.03 & $\mathbf{3 . 7 9}$ \\
\hline Rat IgG & 0.08 & - & 3.15 & 5.02 \\
\hline
\end{tabular}

Table 31 shows the direct ELISA where SpL strongly bind to $13.33 \%$ of the mammalian immunoglobulins. It does not bind to $66.6 \%$ of the panel of immunoglobulins.

SpLA Direct ELISA: This ELISA is used to study the interactions of protein-LA (SpLA) with diverse immunoglobulins. The 96 well microtitre plate is coated overnight at $4^{\circ} \mathrm{C}$ with $1 \mu \mathrm{g} / \mu 1$ per well of purified immunoglobulins in carbonate-bicarbonate buffer $\mathrm{pH} 9.6$. Then, plate is treated with bovine serum albumin solution and washed $4 \mathrm{X}$ with PBS-Tween. Then, $50 \mu 1$ of peroxidase-labeled-protein-LA conjugate diluted 1:3000 in PBS-non-fat milk is added to each well and incubated for $1.30 \mathrm{~h}$ at RT. After that, the plate is washed $4 \mathrm{X}$ with PBS-Tween. Pipette $50 \mu \mathrm{l}$ of 3,3',5,5' - tetramethylbenzidine (TMB; Sigma-Aldrich) to each well. The reaction is stopped with $50 \mu \mathrm{l}$ of $3 \mathrm{M} \mathrm{H} 2 \mathrm{SO} 4$ solution. The plate is visually assessed for the development of colour and read in a microplate reader at $450 \mathrm{~nm}$. A cut-off point is calculated as the mean of the optical density of negative controls times two. The cut-off point is 0.30 . 
Table 32. SpLA Direct ELISA

\begin{tabular}{|l|c|c|c|c|}
\hline Immunoglobulins & XOD results & Binding affinity & $\begin{array}{l}\text { Coefficient of } \\
\text { variation }(\mathbf{C V}) \\
\text { intra-assay }(\%)\end{array}$ & $\begin{array}{l}\text { CV inter-assay } \\
(\%)\end{array}$ \\
\hline Mule IgG & 0.34 & + & 3.53 & 5.05 \\
\hline Donkey IgG & 0.41 & + & 3.88 & 5.61 \\
\hline Horse IgG & 0.68 & ++ & 3.67 & 5.08 \\
\hline Dog IgG & 0.95 & +++ & 4.58 & 6.37 \\
\hline Skunk IgG & 0.91 & +++ & 3.85 & 5.03 \\
\hline Coyote IgG & 0.63 & ++ & 4.77 & 7.18 \\
\hline Raccoon IgG & 0.98 & +++ & 3.75 & 5.89 \\
\hline Ostrich IgY & 0.38 & + & 4.54 & 7.17 \\
\hline Pig IgG & 1.06 & +++ & 5.06 & 8.56 \\
\hline Mouse IgG & 1.15 & +++ & 3.05 & 6.40 \\
\hline Bovine IgG & 0.46 & + & 4.64 & 5.98 \\
\hline Rabbit IgG & 0.96 & +++ & 3.87 & 5.82 \\
\hline Chicken IgY & 0.15 & - & 2.35 & 4.80 \\
\hline Cat IgG & 0.85 & +++ & 3.36 & 5.70 \\
\hline Rat IgG & 0.35 & + & 4.11 & 6.16 \\
\hline
\end{tabular}

It depicts the direct SpLA ELISA, where the bacterial protein binds strongly to immunoglobulins of various species of animals including dog, raccoon, and rabbit. As shown in table 32, indeed, it does not bind to the negative control: the chicken IgY. SpLA is a very versatile reagent that strongly binds to immunoglobulins from many animal species [29].

SpLG Direct ELISA: This ELISA is used to study the interactions of protein-LG (SpLG) with diverse immunoglobulins. The 96 well microtitre plate is coated overnight at $4^{\circ} \mathrm{C}$ with $1 \mu \mathrm{g} / \mu 1$ per well of purified immunoglobulins in carbonate-bicarbonate buffer $\mathrm{pH}$ 9.6. Then, plate is treated with bovine serum albumin solution and washed $4 \mathrm{X}$ with PBS-Tween. Then, 50 . $\mu 1$ of peroxidase-labeled-protein-LG conjugate diluted 1:3000 in PBS-non-fat milk is added to each well and incubated for $1.30 \mathrm{~h}$ at RT. After that, the plate is washed $4 \mathrm{X}$ with PBS-Tween. Pipette $50 \mu \mathrm{l}$ of 3,3',5,5' - tetramethylbenzidine (TMB; Sigma-Aldrich) to each well. The reaction is stopped with $50 \mu \mathrm{l}$ of $3 \mathrm{M} \mathrm{H} 2 \mathrm{SO} 4$ solution. The plate is visually assessed for the development of colour and read in a microplate reader at $450 \mathrm{~nm}$. A cut-off point is calculated as the mean of the optical density of negative controls times two. The cut-off point is 0.30 . 
Table 33. SpLG Direct ELISA.

\begin{tabular}{|l|c|c|c|c|}
\hline Immunoglobulins & XOD results & Binding affinity & $\begin{array}{l}\text { Coefficient of } \\
\text { variation }(\mathbf{C V}) \\
\text { intra-assay }(\%)\end{array}$ & $\begin{array}{l}\text { CV inter-assay } \\
(\%)\end{array}$ \\
\hline Mule IgG & $\mathbf{0 . 6 1}$ & ++ & 3.61 & 6.84 \\
\hline Donkey IgG & 0.72 & ++ & 3.97 & 5.69 \\
\hline Horse IgG & 0.88 & +++ & 5.06 & 7.05 \\
\hline Dog IgG & 1.05 & +++ & 4.15 & 6.40 \\
\hline Skunk IgG & 0.94 & +++ & 3.68 & 6.10 \\
\hline Coyote IgG & 0.35 & + & 4.55 & 7.15 \\
\hline Raccoon IgG & 0.40 & + & 4.76 & 7.90 \\
\hline Ostrich IgY & 0.12 & - & 2.58 & 4.73 \\
\hline Pig IgG & 0.95 & +++ & 4.00 & 6.60 \\
\hline Mouse IgG & 0.97 & +++ & 4.57 & 8.85 \\
\hline Bovine IgG & 0.88 & ++ & 5.86 & 8.05 \\
\hline Rabbit IgG & 0.95 & +++ & 3.55 & 6.30 \\
\hline Chicken IgY & 0.15 & - & 3.10 & 4.78 \\
\hline Cat IgG & 0.07 & - & 2.95 & 4.07 \\
\hline Rat IgG & 1.18 & +++ & 3.22 & 6.78 \\
\hline
\end{tabular}

Table 33 depicts the indirect ELISA, where SpLG strongly interacts with $46.66 \%$ of the panel of immunoglobulins. It has been shown to be a versatile IgG-binding reagent. It bound to mouse and rat IgG, and many other immunoglobulins and antibody fragments [30].

SpAG Direct ELISA: This ELISA is used to study the interactions of protein-AG (SpAG) with diverse immunoglobulins. The 96 well microtitre plate is coated overnight at $4^{\circ} \mathrm{C}$ with $1 \mu \mathrm{g} / \mu 1$ per well of purified immunoglobulins in carbonate-bicarbonate buffer $\mathrm{pH}$ 9.6. Then, plate is treated with bovine serum albumin solution and washed $4 \mathrm{X}$ with PBS-Tween. Then, $50 \mu 1$ of peroxidase-labeled-protein-AG conjugate diluted 1:3000 in PBS-non-fat milk is added to each well and incubated for $1.30 \mathrm{~h}$ at RT. After that, the plate is washed $4 \mathrm{X}$ with PBS-Tween. Pipette $50 \mu \mathrm{l}$ of 3,3',5,5' - tetramethylbenzidine (TMB; Sigma-Aldrich) to each well. The reaction is stopped with $50 \mu \mathrm{l}$ of $3 \mathrm{M} \mathrm{H} 2 \mathrm{SO} 4$ solution. The plate is visually assessed for the development of colour and read in a microplate reader at $450 \mathrm{~nm}$. A cut-off point is calculated as the mean of the optical density of negative controls times two. The cut-off point is 0.28. 
Table 34. SpAG Direct ELISA

\begin{tabular}{|l|c|c|c|c|}
\hline Immunoglobulins & XOD results & Binding affinity & $\begin{array}{l}\text { Coefficient of } \\
\text { variation }(\mathbf{C V}) \\
\text { intra-assay }(\%)\end{array}$ & $\begin{array}{l}\text { CV inter-assay } \\
(\%)\end{array}$ \\
\hline Mule IgG & $\mathbf{0 . 4 2}$ & + & 3.50 & 5.07 \\
\hline Donkey IgG & 0.44 & + & 4.05 & 7.14 \\
\hline Horse IgG & $\mathbf{0 . 6 5}$ & ++ & 4.15 & 5.90 \\
\hline Dog IgG & 1.12 & +++ & 3.28 & 5.32 \\
\hline Skunk IgG & 1.18 & +++ & 3.58 & 5.78 \\
\hline Coyote IgG & 0.44 & + & 3.67 & 6.60 \\
\hline Raccoon IgG & 1.05 & +++ & 4.06 & 6.81 \\
\hline Ostrich IgY & 0.35 & + & 2.74 & 4.78 \\
\hline Pig IgG & 1.15 & +++ & 4.79 & 7.67 \\
\hline Mouse IgG & 1.09 & +++ & 4.07 & 8.20 \\
\hline Bovine IgG & 0.65 & ++ & 5.13 & 8.05 \\
\hline Rabbit IgG & 1.12 & +++ & 3.76 & 6.03 \\
\hline Chicken IgY & 0.14 & - & 3.43 & 5.79 \\
\hline Cat IgG & 1.19 & +++ & 3.17 & 4.83 \\
\hline Rat IgG & 0.58 & ++ & 3.45 & 5.26 \\
\hline
\end{tabular}

Table 34 shows SpAG that binds strongly to $46.66 \%$ of the immunoglobulin panel. As compared with SpLG, SpAG interacts with the entire panel except the chicken IgY, and SpLG lacks affinity to IgY of ostriches and chickens and does not interact with the cat IgG.

PLAG Direct ELISA: This ELISA is used to study the interactions of protein-LAG (PLAG) with diverse immunoglobulins. The 96 well microtitre plate is coated overnight at $4^{\circ} \mathrm{C}$ with 1 $\mu \mathrm{g} / \mu \mathrm{l}$ per well of purified immunoglobulins in carbonate-bicarbonate buffer $\mathrm{pH} 9.6$. Then, plate is treated with bovine serum albumin solution and washed $4 \mathrm{X}$ with PBS-Tween. Then, $50 \mu 1$ of peroxidase-labeled-protein-LAG conjugate diluted 1:3000 in PBS-non-fat milk is added to each well and incubated for $1.30 \mathrm{~h}$ at RT. After that, the plate is washed $4 \mathrm{X}$ with PBS-Tween. Pipette $50 \mu \mathrm{l}$ of 3,3',5,5' - tetramethylbenzidine (TMB; Sigma-Aldrich) to each well. The reaction is stopped with $50 \mu \mathrm{l}$ of $3 \mathrm{M} \mathrm{H} 2 \mathrm{SO} 4$ solution. The plate is visually assessed for the development of colour and read in a microplate reader at $450 \mathrm{~nm}$. A cut-off point is calculated as the mean of the optical density of negative controls times two. The cut-off point is 0.30 . 
Table 35. PLAG Direct ELISA.

\begin{tabular}{|l|c|c|c|c|}
\hline Immunoglobulins & XOD results & Binding affinity & $\begin{array}{l}\text { Coefficient of } \\
\text { variation }(\mathbf{C V}) \\
\text { intra-assay }(\%)\end{array}$ & $\begin{array}{l}\text { CV inter-assay } \\
(\%)\end{array}$ \\
\hline Mule IgG & $\mathbf{0 . 9 7}$ & +++ & 4.22 & 7.16 \\
\hline Donkey IgG & 1.05 & +++ & 4.34 & 8.38 \\
\hline Horse IgG & 0.94 & +++ & 3.92 & 7.26 \\
\hline Dog IgG & 1.00 & +++ & 4.04 & 7.85 \\
\hline Skunk IgG & 1.32 & +++ & 3.50 & 6.37 \\
\hline Coyote IgG & 0.65 & ++ & 4.60 & 7.28 \\
\hline Raccoon IgG & 1.25 & +++ & 3.68 & 6.34 \\
\hline Ostrich IgY & $\mathbf{0 . 4 9}$ & + & 3.65 & 6.05 \\
\hline Pig IgG & 1.45 & +++ & 4.09 & 7.18 \\
\hline Mouse IgG & 1.35 & +++ & 4.75 & 8.40 \\
\hline Bovine IgG & 0.72 & ++ & 4.38 & 6.47 \\
\hline Rabbit IgG & 1.18 & +++ & 4.15 & 7.03 \\
\hline Chicken IgY & 0.15 & - & 3.65 & 5.70 \\
\hline Cat IgG & 1.10 & +++ & 4.08 & 6.74 \\
\hline Rat IgG & 0.95 & +++ & 3.15 & 4.78 \\
\hline
\end{tabular}

Table 35 shows a PLAG direct ELISA. This hybrid immunoglobulin-binding protein binds strongly to IgGs from eleven species of animals, which represents $73.33 \%$. In addition, it binds moderately to IgGs of several species as coyote and bovine. This is a very versatile reagent, with the capacity to bind to immunoglobulins from many animal species.

The 35 ELISAs were highly reproducible and this is a confirmatory results for some of the ELISAs that have been reported previously as direct (SpL, SpA, SpLA), and sandwich ELISA as SpG-SpLA assay $[9,20,25]$. The reason why we report that these tests were highly reproducible is the fact that their coefficient of variation (both intra-assays and inter-assays) were within the normal limits except for few immunoglobulin samples. The intra-assay reproducibility was 98.09\% (515 tests out of 525 of the samples had CV within the normal limit that were below $5 \%$ ). The inter-assay reproducibility was $99.62 \%$ (meaning that 523 tests out of 525 tests had CV that were below 10\%).

Most of the ELISAs are newly reported in this research. They were standardized after a detailed basic ELISA protocol workout. Quantities of proteins being coated in the microplate, washing procedures, optimal sample concentration, optimal dilutions of the conjugates, and optimal molarity of the stop solution reagent were assessed.

It is recommended for further work to test the IgG-binding reagents in ELISAs for immunodetection of zoonotic microorganisms affecting a greater number of mammalian species, 
as the case of Borrelia burgdorferi. Another suggestion is the demonstration of the binding affinities of immunoglobulin-binding proteins to antibodies of many animal species by Western blot analysis or dot blot analysis.

\section{Indirect ELISA for detection of anti-HIV antibodies in cats or rats and dot blot results.}

Cats, chickens, and rats raised antibodies against a fragment of HIV gp120 that were detected by ELISA and confirmed by dot blot analyses as shown in figures 2 and 3. The authors are not aware of any other documented study describing the use of anti-HIV hyper-immune chicken eggs as oral vaccine. Thibodeau and Tremblay (1991) reported that human immunodeficiency virus (HIV-1) gp160-specific secretory IgA was found in the saliva of rabbits orally immunized with a HIV-immunosome. These antibodies neutralized HIV infectivity in vitro [31].

Figure 2 shows dot blotting lines that represent anti-HIV antibodies, which are present in 3 cat sera, orally immunized with anti-HIV hyperimmune chicken eggs. It shows anti-HIV antibodies in the serum from two infected humans (the sera were donated by the National Blood Bank in the Caribbean and it was used as a positive control). No dot blot signals are present in negative controls (sera from two un-fed cats and an HIV negative human serum sample).

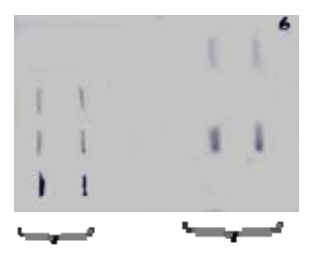

Cats Humans

Figure 2 shows dot blotting lines that represent anti-HIV antibodies, which are present in 3 cat sera, orally immunized with anti-HIV hyperimmune chicken eggs. It shows anti-HIV antibodies in the serum from two infected humans (the sera were donated by the National Blood Bank in the Caribbean and it was used as a positive control). No dot blot signals are present in negative controls (sera from two unfed cats and an HIV negative human).

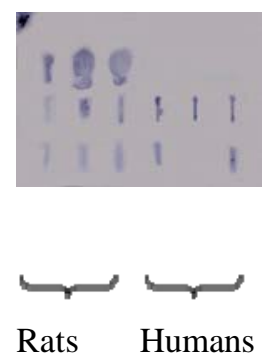

Figure 3 shows 9 dots that represent the presence of anti-HIV antibodies in 3 rats orally immunized with hyperimmune egg raised against the fragment peptide 254-274 of HIV gp120. It shows 5 dots that represent 2 human sera also positive for HIV and were used here as positive controls. The blank spaces represent negative samples or blanks. 
Acknowledgements: To the Campus Research and Publication Fund of the University of West Indies, Mona Campus, Jamaica. West Indies. I have gratitude for Professors Norma Anderson and Monica Smikle from University of the West Indies for guidance and support.

Conflict of interest: The authors declare no conflicts of interest exist.

Research Grant: The research was funded by a grant provided by The Caribbean Health Research Council (CHRC) under the CARICOM/EU project on Strengthening the Institutional Response to HIV/AIDS/STIs.

Conclusions: The single and hybrid immunoglobulin-binding protein were effective in their binding capacity to immunoglobulins from a variety of mammalian species. The potential use of this proteins is in the arena of immunodiagnosis and immunoglobulin detection. Dot blot analysis proves effective in the detection of HIV anti-gp120 antibodies in several animal species including cats, rats, and positive human controls. These antibodies can be used as reagents in the development of immunodiagnostic tests or oral vaccines as the use of hyper-immune chicken eggs.

\section{References}

1. Justiz-Vaillant A, McFarlane-Anderson N, and Smikle MF, "Bacterial Immunoglobulin (Ig)-Receptors: Past and Present Perspectives." American Journal of Microbiological Research, vol. 5, no. 2 (2017): 44-50. doi: 10.12691/ajmr-5-2-4.

2. Forsgren A, Sjöquist J. "Protein A" from S. aureus. I. Pseudoimmune reaction with human gamma-globulin. J Immunol 1966, 97(6): 822-7.

3. Kronvall G. A surface component in group A, C, and G streptococci with nonimmune reactivity for immunoglobulin G. J Immunol 1973, 111(5): 1401-6.

4. Björck L, Kronvall G. Purification and some properties of streptococcal protein G, a novel IgG-binding reagent. J Immunol 1984, 133(2): 969-74. [4]

5. Björck L. Protein L. A novel bacterial cell wall protein with affinity for Ig L chains. J Immunol 1988, 15; 140(4):1194-7.

6. Richman DD, Cleveland PH, Oxman MN, Johnson KM. The binding of staphylococcal protein A by the sera of different animal species. J Immunol 1982, 128(5): 2300-5.

7. De Château M, Nilson BH, Erntell M, Myhre E, Magnusson CG, Akerström B, Björck L. On the interaction between protein $\mathrm{L}$ and immunoglobulins of various mammalian species. Scand J Immunol 1993, 37(4): 399-405.

8. Svensson HG, Hoogenboom HR, Sjöbring U. Protein LA, a novel hybrid protein with unique single-chain Fv antibody- and Fabbinding properties. Eur J Biochem 1998, 258(2): 890-6.

9. Justiz-Vaillant AA, McFarlane-Andersonv N, Wisdom B, Mohammed W, Vuma S, et al. Immunoglobulin-binding Bacterial Proteins (IBP) Conjugates and their Reactivity with Immunoglobulin in Enzyme-Linked Immunosorbent Assays (ELISA). J Anal Bioanal Tech 2013, 4: 175. doi: 10.4172/2155-9872.1000175. 
10. Stöbel K, Schönberg A, Staak C. A new non-species dependent ELISA for detection of antibodies to Borrelia burgdorferi s. 1. in zoo animals. Int J Med Microbiol. 2002, 291 Suppl 33: 88-99.

11. Cai SY, Wang YY, Yao ZJ. Engineered bacterial Fc receptors. Sci China B 1994, 37(4): 454-61.

12. Zhang SY, Wei MX, Zhou ZY, Yu JY, Shi XQ. Prevalence of antibodies to Toxoplasma gondii in the sera of rare wildlife in the Shanghai Zoological Garden, People's Republic of China. Parasitol Int 2000, 49(2): 171-4.

13. Mebatsion T, Frost JW, Krauss H. Enzyme-linked immunosorbent assay (ELISA) using staphylococcal protein A for the measurement of rabies antibody in various species. Zentralbl Veterinarmed B 1989, 36(7): 532-6.

14. Kelly PJ, Tagwira M, Matthewman L, Mason PR, Wright EP. Reactions of sera from laboratory, domestic and wild animals in Africa with protein A and a recombinant chimeric protein AG. Comp Immunol Microbiol Infect Dis 1993, 16(4): 299-305.

15. Guss B, Eliasson M, Olsson A, Uhlén M, Frej AK, Jörnvall H, Flock JI, Lindberg M. Structure of the IgG-binding regions of streptococcal protein G. EMBO J 1986, 5(7): 1567-75.

16. Akerström B, Björck L. A physicochemical study of protein G, a molecule with unique immunoglobulin G-binding properties. J Biol Chem 1986, 261(22): 10240-7.

17. Akerström B, Brodin T, Reis K, Björck L. Protein G: a powerful tool for binding and detection of monoclonal and polyclonal antibodies. J Immunol 1985, 135(4): 25892592.

18. Kastern W, Sjöbring U, Björck L. Structure of peptostreptococcal protein L and identification of a repeated immunoglobulin light chain-binding domain. J Biol Chem 1992, 267(18): 12820-5.

19. Wikström M, Sjöbring U, Drakenberg T, Forsén S, Björck L. Mapping of the immunoglobulin light chain-binding site of protein L. J Mol Biol 1995, 250(2): 12833.

20. Vaillant AJ, Mohammed W, Vuma S, Kurhade A, Kurhade G (2016) Purification of Immunoglobulins and their Binding to a Bacterial Protein LAG-HRP Conjugate. J Veterinar Sci Technol 7: 288. doi:10.4172/2157-7579.1000288.

21. Neville DM Jr (1971) Molecular weight determination of protein-dodecyl sulfate complexes by gel electrophoresis in a discontinuous buffer system. J Biol Chem 246: 6328-6334.

22. Justiz Vaillant AA, Akpaka PE, McFarlane-Anderson N, Smikle MP, Wisdom B (2012) Purification of Immunoglobulin Y (IgY) from the Ostrich (Struthio camelus) by Staphylococcal Protein a (Spa) Affinity Chromatography. J Chromat Separation Techniq 3:127. doi: 10.4172/2157- 7064.1000127.

23. Polson A (1990) Isolation of IgY from the yolks of eggs by a chloroform polyethylene glycol procedure. Immunol Invest 19: 253-258.

24. Nakane PK, Kawaoi A (1974) Peroxidase-labeled antibody. A new method of conjugation. J Histochem Cytochem 22: 1084-1091.

25. Justiz-Vaillant A, Akpaka PE, McFarlane-Anderson N, Smikle MF (2013) Comparison of Techniques of Detecting Immunoglobulin-binding Protein 
Reactivity to Immunoglobulin Produced by Different Avian and Mammalian Species. West Indian Medical Journal 62: 12-20.

26. Ho DD, Kaplan JC, Rackauskas IE, Gurney ME. Second conserved domain of gp120 is important for HIV infectivity and antibody neutralization. Science. $1988 \mathrm{Feb}$ 26;239(4843):1021-3. doi: 10.1126/science.2830667.

27. Vaillant AAJ, Akpaka PE, McFarlane-Anderson N, Smikle MP, Brian W (2012) The Chicken and Egg System for the Development of Anti-Idiotypic Vaccines. J Vaccines Vaccin 3:137 doi:10.4172/2157-7560.1000137.

28. Justiz-Vaillant A, McFarlane-Anderson N, Akpaka PE, Smikle MF, Ramirez N, et al. (2013) Use of Dot Blots Analysis in the Separation of Anti-HIV Antibodies in Animals. Journal of Chromatography \& Separation Techniques 4: 181. doi: doi:10.4172/2157- 7064.1000181.

29. Svensson HG, Hoogenboom HR, Sjöbring U. Protein LA, a novel hybrid protein with unique single-chain Fv antibody- and Fabbinding properties. Eur J Biochem 1998, 258(2): 890-6.

30. Kihlberg BM, Sjöbring U, Kastern W, Björck L. Protein LG: a hybrid molecule with unique immunoglobulin binding properties. J Biol Chem. 1992 Dec 15;267(35):25583-8.

31. Thibodeau L, Tremblay C, Lachapelle L. Une immunisation orale et parentérale avec l'immunosome-VIH induit une sécrétion d'IgA spécifique du VIH-1 dans la salive et la production d'IgA circulants chez la souris et le lapin [Oral and parenteral immunization with HIV immunosome induce the secretion of IgA specific of HIV-1 in the salivary and the production of circulatory $\operatorname{IgA}$ in mice and rabbits]. C R Acad Sci III. 1991;313(9):389-94. 